Prepared in cooperation with the

U.S. Department of Homeland Security-Federal Emergency Management Agency

\title{
Simulated and Observed 2010 Flood-Water Elevations in Selected River Reaches in the Moshassuck and Woonasquatucket River Basins, Rhode Island
}

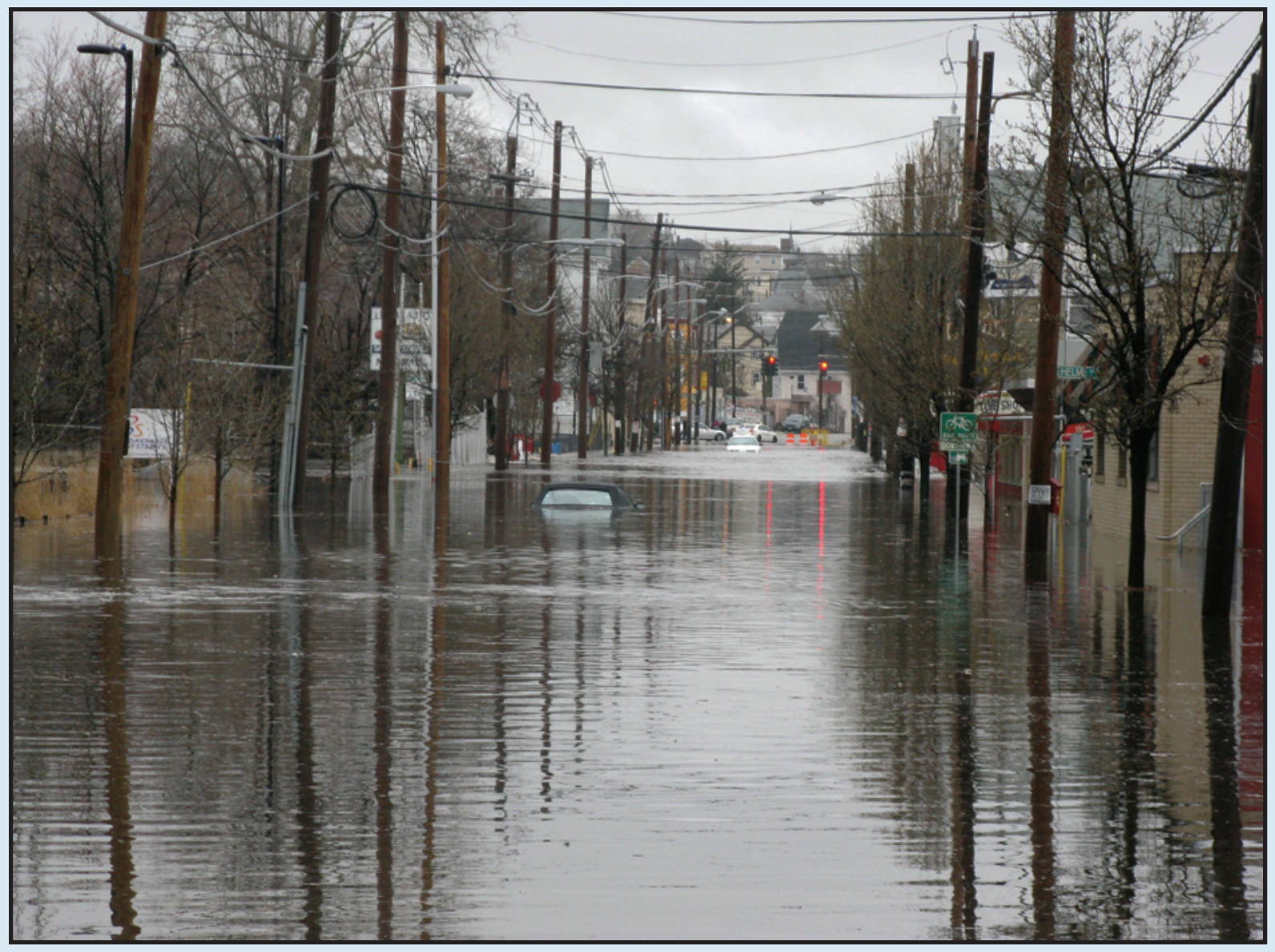

Scientific Investigations Report 2013-5191 
Front cover. Photograph of Woonasquatucket River flooding on Valley Street looking toward Atwells Avenue, Providence, Rhode Island. 


\section{Simulated and Observed 2010 Flood-Water Elevations in Selected River Reaches in the Moshassuck and Woonasquatucket River Basins, Rhode Island}

By Phillip J. Zarriello, David E. Straub, and Stephen M. Westenbroek

Prepared in cooperation with the

U.S. Department of Homeland Security-Federal Emergency Management Agency

Scientific Investigations Report 2013-5191 


\title{
U.S. Department of the Interior SALLY JEWELL, Secretary
}

\section{U.S. Geological Survey Suzette M. Kimball, Acting Director}

\author{
U.S. Geological Survey, Reston, Virginia: 2014
}

For more information on the USGS - the Federal source for science about the Earth, its natural and living resources, natural hazards, and the environment, visit http://www.usgs.gov or call 1-888-ASK-USGS.

For an overview of USGS information products, including maps, imagery, and publications, visit http://www.usgs.gov/pubprod

To order this and other USGS information products, visit http://store.usgs.gov

Any use of trade, firm, or product names is for descriptive purposes only and does not imply endorsement by the U.S. Government.

Although this information product, for the most part, is in the public domain, it also may contain copyrighted materials as noted in the text. Permission to reproduce copyrighted items must be secured from the copyright owner.

Suggested citation:

Zarriello, P.J., Straub, D.E., and Westenbroek, S.M., 2014, Simulated and observed 2010 flood-water elevations in selected river reaches in the Moshassuck and Woonasquatucket River Basins, Rhode Island: U.S. Geological Survey Scientific Investigations Report 2013-5191, 35 p., http://dx.doi.org/10.3133/sir20135191. 


\section{Contents}

Abstract
Introduction
Purpose and Scope
Previous Studies
Hydraulic Models
Structure and Cross-Section Updates
Flood-Flow Updates
Summarison of 2010 Flood High-Water Marks with Simulated Water Levels
References Cited.
Appendix 1. Moshassuck and Woonasquatucket River Basin Hydraulic Models:
Technical Data Support Notebook

\section{Figures}

1. Map showing Moshassuck and Woonasquatucket River Basins, Rhode Island ...............3

2. Map showing high-water marks obtained after the 2010 flood along reaches of detailed hydraulic analysis in the Moshassuck and Woonasquatucket Rivers, Rhode Island

3. Graph showing the difference between the 2010 flood high-water mark (HWM) elevations and water-surface elevations from the effective flood insurance study (FIS) and updated hydraulic model.

4. Boxplot showing differences between the 2010 flood high-water mark (HWM) elevations and water-surface elevations from the effective flood insurance study (FIS) and updated hydraulic models at the 1-percent annual exceedance probability (AEP) in the Moshassuck River and at the 2-percent AEP in the Woonasquatucket River, Rhode Island.

5. Map showing flood inundation at the 2-percent annual exceedance probability along the Woonasquatucket River at Valley Street in Providence, Rhode Island, where the photograph in figure 6 was taken .

6. Photograph of Woonasquatucket River flooding on Valley Street looking toward Atwells Avenue, Providence, Rhode Island 


\section{Tables}

1. Reaches in the Moshassuck and Woonasquatucket River Basins where detailed hydraulic analyses were done

2. Summary of structures surveyed, the number of structures represented, and total number of cross sections in the hydraulic models of the Moshassuck and Woonasquatucket River Basins.

3. Comparison of flood insurance study and updated flood flows for selected annual exceedance probabilities in selected reaches in the Moshassuck and Woonasquatucket River Basins, Rhode Island

4. Comparison of the 2010 flood high-water mark (HWM) elevations to the effective flood insurance study (FIS) and updated hydraulic model water-surface elevations at the 1-percent annual exceedance probability (AEP) in the Moshassuck River and the 2-percent AEP in the Woonasquatucket River, Rhode Island

\section{Conversion Factors, Datum, and Abbreviations}

Inch/Pound to SI

\begin{tabular}{lcl}
\hline \multicolumn{1}{c}{ Multiply } & By & \multicolumn{1}{c}{ To obtain } \\
\hline foot $(\mathrm{ft})$ & Length & \\
mile $(\mathrm{mi})$ & 0.3048 & meter $(\mathrm{m})$ \\
& 1.609 & kilometer $(\mathrm{km})$ \\
\hline square foot $\left(\mathrm{ft}^{2}\right)$ & Area & \\
square mile $\left(\mathrm{mi}^{2}\right)$ & 0.09290 & square meter $\left(\mathrm{m}^{2}\right)$ \\
& 259.0 & hectare $(\mathrm{ha})$ \\
\hline cubic foot per second $\left(\mathrm{ft}^{3} / \mathrm{s}\right)$ & Flow rate & \\
\hline
\end{tabular}

Vertical coordinate information is referenced to North American Vertical Datum of 1988 (NAVD 88).

Horizontal coordinate information is referenced to North American Datum of 1983 (NAD 83).

Elevation, as used in this report, refers to distance above the vertical datum. 


\section{Abbreviations}

$\begin{array}{ll}\text { AEP } & \text { annual exceedance probability } \\ \text { DFIRM } & \text { digital flood rate insurance map } \\ \text { FEMA } & \text { Federal Emergency Management Agency } \\ \text { FIS } & \text { flood insurance study; effective FIS is the latest FIS approved by FEMA } \\ \text { FPHB } & \text { Fox Point Hurricane Barrier } \\ \text { GPS } & \text { global positioning system } \\ \text { HEC-GeoRAS } & \text { Geographic support tool for HEC-RAS } \\ \text { HEC-RAS } & \text { Hydrologic Engineering Center-River Analysis System } \\ \text { HWM } & \text { high-water mark } \\ \text { LiDAR } & \text { light detection and ranging } \\ \text { NAD 83 } & \text { North American Datum of 1983 (horizontal datum) } \\ \text { NAVD 88 } & \text { North American Vertical Datum of 1988 (vertical datum) } \\ \text { NHD } & \text { National hydrography dataset } \\ \text { TSDN } & \text { Technical Support Data Notebook } \\ \text { USACE } & \text { U.S. Army Corps of Engineers } \\ \text { USGS } & \text { U.S. Geological Survey } \\ \text { WSE } & \text { water-surface elevation }\end{array}$


THIS PAGE INTENTIONALLY LEFT BLANK 


\title{
Simulated and Observed 2010 Flood-Water Elevations in Selected River Reaches in the Moshassuck and Woonasquatucket River Basins, Rhode Island
}

\author{
By Phillip J. Zarriello, David E. Straub, and Stephen M. Westenbroek
}

\section{Abstract}

Heavy persistent rains from late February through March 2010 caused severe flooding and set, or nearly set, peaks of record for streamflows and water levels at many longterm U.S. Geological Survey streamgages in Rhode Island. In response to this flood, hydraulic models were updated for selected reaches covering about 33 river miles in Moshassuck and Woonasquatucket River Basins from the most recent approved Federal Emergency Management Agency flood insurance study (FIS) to simulate water-surface elevations (WSEs) from specified flows and boundary conditions. Reaches modeled include the main stem of the Moshassuck River and its main tributary, the West River, and three tributaries to the West River-Upper Canada Brook, Lincoln Downs Brook, and East Branch West River; and the main stem of the Woonasquatucket River. All the hydraulic models were updated to Hydrologic Engineering Center-River Analysis System (HEC-RAS) version 4.1.0 and incorporate new field-survey data at structures, high-resolution land-surface elevation data, and flood flows from a related study.

The models were used to simulate steady-state WSEs at the 1- and 2-percent annual exceedance probability (AEP) flows, which is the estimated AEP of the 2010 flood in the Moshassuck River Basin and the Woonasquatucket River, respectively. The simulated WSEs were compared to the high-water mark (HWM) elevation data obtained in these basins in a related study following the March-April 2010 flood, which included 18 HWMs along the Moshassuck River and 45 HWMs along the Woonasquatucket River. Differences between the 2010 HWMs and the simulated 2- and 1-percent AEP WSEs from the FISs and the updated models developed in this study varied along the reach. Most differences could be attributed to the magnitude of the 2- and 1-percent AEP flows used in the FIS and updated model flows. Overall, the updated model and the FIS WSEs were not appreciably different when compared to the observed 2010 HWMs along the Woonasquatucket and Moshassuck Rivers.

\section{Introduction}

Persistent heavy rains from late February through March 2010 caused severe flooding that set, or nearly set, record streamflows and water levels, causing a state of emergency to be declared in many communities in Rhode Island. An Emergency Declaration was declared on March 30, 2010 (Rhode Island Severe Storms and Flooding (EM-3311), http:/www.fema.gov/disasters/3311), which affected the emergency-recovery operations in all counties in Rhode Island. The flood was characterized as the worst in 200 years with damages estimated in many millions of dollars. As part of the recovery operations, the U.S. Department of Homeland Security-Federal Emergency Management Agency (FEMA) required analysis of the flood to help assess damages and to minimize future flood damages.

In a related FEMA-supported study, flood magnitudes were determined at U.S. Geological Survey (USGS) streamgages and regional flood-flow equations were developed for ungaged sites over a range of annual exceedance probabilities (AEPs) for Rhode Island (Zarriello and others, 2012). The magnitude of floods for different AEPs is an important part of determining flood-prone areas and risk assessment. Floods for a given magnitude are simulated through hydraulic models of a river reach that converts the flow into water levels along the reach on the basis of the river capacity or conveyance. This information then is used for delineation of flood zones, flood-plain management operations, infrastructure design, and other purposes.

The USGS entered into an agreement with FEMA in August 2010 to document and characterize the MarchApril 2010 flood. As part of the agreement, the USGS updated hydraulic models for selected reaches, which are used to simulate flood water-surface elevations (WSEs) over a range of AEPs flows. The simulated WSEs made with the updated hydraulic models, along with WSEs from the flood insurance studies (FISs), were evaluated in comparison to high-water marks (HWMs) from the March-April 2010 flood in the Moshassuck and Woonasquatucket River Basins in 
Rhode Island. The updated hydraulic models are important for post-flood analysis and provide tools for future floodmanagement needs.

\section{Purpose and Scope}

The purpose of this report is to document the development of Hydrologic Engineering Center-River Analysis System (HEC-RAS) hydraulic models (Brunner, 2010a and b) that were used to simulate WSEs over a range of AEPs flood flows in the Moshassuck and Woonasquatucket River Basins. The WSEs computed with updated models are compared to WSEs reported in the effective FIS (the latest FIS approved by FEMA) and to the March-April 2010 HWM elevations, which was estimated to have a 1- and 2-percent AEP in the Moshassuck and Woonasquatucket River Basins, respectively.

Hydraulic models were developed for the Woonasquatucket River and Moshassuck River and four tributary reaches in the Moshassuck River Basin-West River, Upper Canada Brook, Lincoln Downs Brook, and East Branch West River. Appendix 1 provides information similar to Technical Support Data Notebook (TSDN) guidelines (FEMA, 2011) for documenting hydraulic models for FISs.

\section{Study Area}

The Moshassuck and Woonasquatucket River Basins cover an area of about 24 and 51 square miles $\left(\mathrm{mi}^{2}\right)$, respectively, in north-central Rhode Island (fig. 1). The rivers merge about 0.9 miles (mi) upstream from the Fox Point Hurricane Barrier (FPHB) at the northern end of Narragansett Bay in the City of Providence. At their confluence, the rivers become the Providence River, which was simulated as part of the Woonasquatucket hydraulic model. The flows and WSEs of the Providence River and lower portions of the Woonasquatucket and Moshassuck Rivers can be affected by tides when the barrier gates are open or by the operation of the barrier when the gates are closed.

Hydraulic models were developed for about a $17.2 \mathrm{mi}$ reach of the Moshassuck River and four tributary reaches and about a $15.4 \mathrm{mi}$ reach of the Woonasquatucket River. Tributaries to Moshassuck River include the West River and three of its tributaries-East Branch West River, Lincoln Downs Brook, and Upper Canada Brook. The main stem reaches are moderate gradient rivers that run north and northwest from the mouth at Narragansett Bay through heavily urbanized areas that become steeper and less urbanized toward their headwaters.

The Moshassuck and Woonasquatucket River Basins are in Providence County and are in parts of the cities of Providence and Pawtucket, and the towns of North Providence, Lincoln, Johnston, and Smithfield. A section of the Woonasquatucket River forms the divide between the towns of North Providence and Johnston.

\section{Previous Studies}

The Moshassuck and Woonasquatucket River Basin hydrology and hydraulic analyses are described in the FIS for Providence County (FEMA, 2009; no. 44007CV001A). The countywide FIS revises and supersedes all previous community FIS reports that generally were first developed by town or city in the 1970s in response to the National Flood Insurance Act of 1968 and the Flood Disaster Protection Act of 1973 and were updated in various years. Community reports, which were limited in extent to community boundaries, are summarized in the countywide report. The hydrology and hydraulic analyses reflect a variety of analytical techniques and hydraulic models depending on who did the study and when it was done. Previous FIS specific flows generally were consistent across community boundaries, but different values were sometimes reported. Although the community FIS studies were revised over time, the countywide FIS (FEMA, 2009) hydrologic analyses appear to be the same as those reported in the earliest community FISs. In some instances, the effective FIS did not report flow values for a reach.

Flood flows reported for the Moshassuck and Woonasquatucket Rivers in the Providence County FIS (FEMA, 2009) generally can be traced back to peak-flow analysis of streamgage records from Moshassuck River at Providence, R.I. (01114000) and the Woonasquatucket River at Centerdale, R.I. (01114500) from the first community FIS report. The length of record used in the analyses was not reported, but it was assumed to be for the period of record through the time of analysis. Flood flows in the tributary reaches of the Moshassuck River Basin (West River, East Branch West River, Lincoln Downs Brook, and Upper Canada Pond Brook) were determined by use of the rainfall-runoff model TR-20 (U.S. Department of Agriculture, 1965) as part of the Town of North Providence FIS (FEMA, 1999). TR-20 simulates flows from the Natural Resources Conservation Service (NRCS), formerly the Soil Conservation Service (SCS), type-III precipitation distribution of the 48-hour total precipitation for the corresponding AEP flood flows. For example, the runoff produced by a 100-year (1-percent AEP) 48 hour rainfall was assumed equal to a 1-percent AEP flood flow. Total precipitation was obtained from National Weather Service Atlas Technical Publication 40 (TP-40) (U.S. Department of Commerce, 1961). The Providence County FIS report (FEMA, 2009) indicates that flows in the West River and Upper Canada Brook were determined from flood-flow equations developed by Johnson and Laraway (1976).

Flood flows were determined from at-site analysis of the streamgage annual peak-flow records through 2010 and regional-regression equations for estimating flood flows at ungaged sites by Zarriello and others (2012). Estimates of uncertainty of the at-site and regression values are provided and were combined with their respective estimated flood quantiles to improve estimates of flood flows at streamgages. 


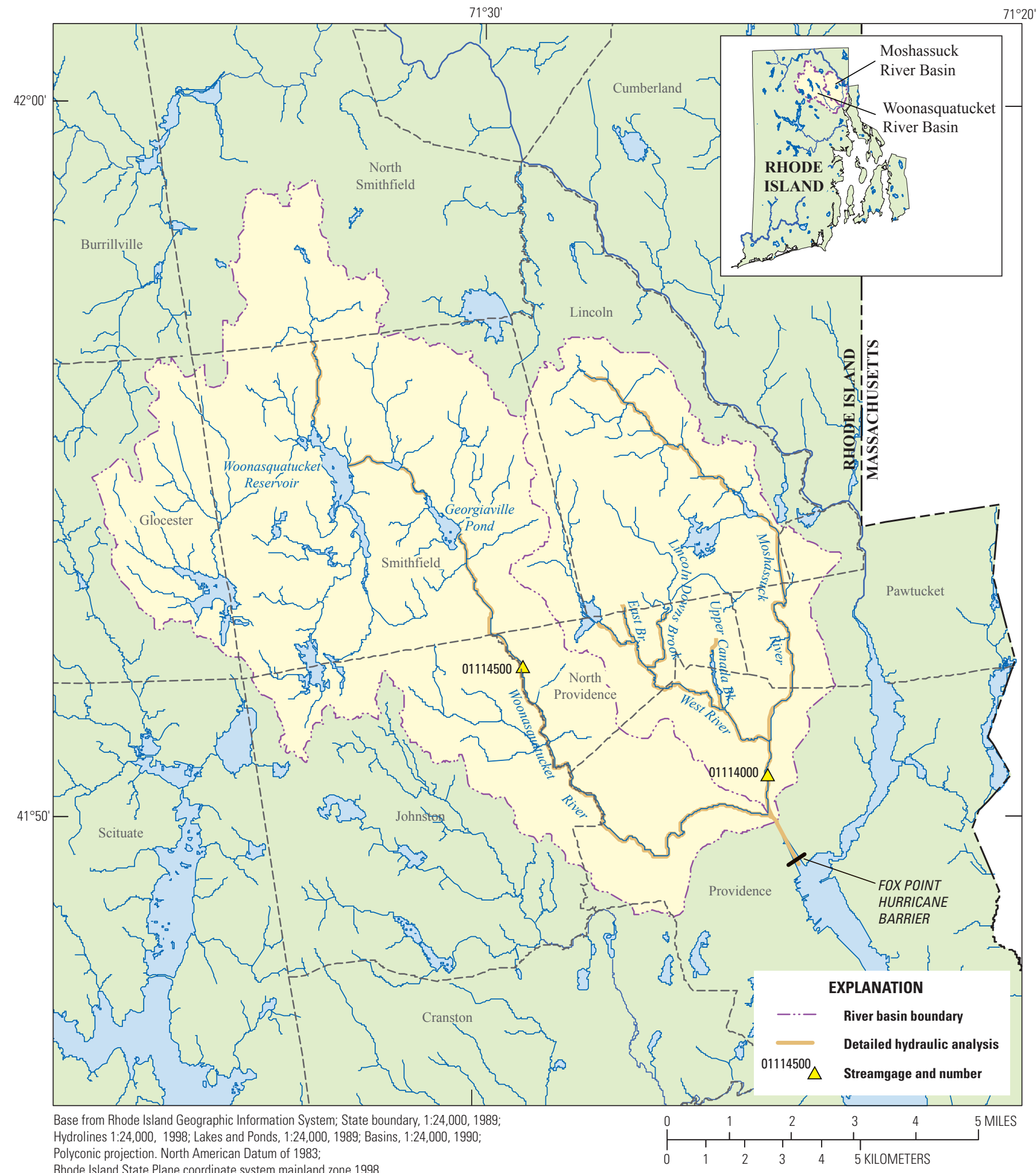

Figure 1. Moshassuck and Woonasquatucket River Basins, Rhode Island. 
Following the record March-April 2010 flooding, 23 HWMs were obtained by the U.S. Army Corps of Engineers (USACE) along the main stem of the Moshassuck River, and 48 HWMs were obtained by the USGS along the main stem of the Woonasquatucket River (Zarriello and Bent, 2011). The HWM elevations were surveyed to North American Vertical Datum of 1988 (NAVD 88). Several HWMs could not be found or were destroyed, which limited HWM elevations to 18 sites on the Moshassuck River and to 45 sites on the Woonasquatucket River. These flood elevations were used to compare to simulated flood elevations for similar exceedance probability floods reported in FISs and developed in this study with updated models.

\section{Hydraulic Models}

Existing hydraulic models for selected reaches in the Moshassuck and Woonasquatucket River Basins were updated to HEC-RAS version 4.1.0 (Brunner, 2010a and b), a onedimensional hydraulic model. Steady-state flow conditions were simulated for specified flows, boundary conditions, and the river's flow carrying capacity or conveyance. The flows input to the model were from selected AEP floods using information and methods developed by Zarriello and others (2012). All WSEs reported in this study are in feet and referenced to the NAVD 88. Revisions of hydraulic models were made to high-priority reaches identified by the Rhode Island Emergency Management Agency in consultation with FEMA; the high-priority reaches identified in the Moshassuck and Woonasquatucket River Basins cover about 33 river miles (table 1; fig. 1).

Input data from existing hydraulic models were obtained from archived (microfiche) files of HEC-2 or WSP-2 models developed for community FISs and converted to the input format for HEC-RAS. HEC-2 (U.S. Army Corps of Engineers, 1991) and WSP-2 (Water Surface Profile program) developed by the U.S. Department of Agriculture (1976) are step-backwater hydraulic models, which were in use at the time of the earlier FISs.

\section{Structure and Cross-Section Updates}

Early in the study it became apparent that the existing hydraulic models did not always reflect current conditions and updated information at structures, such as bridges, culverts, and dams, and their approaches and exits, were needed to better reflect the current conveyance capacity of the reach. As part of this study, field surveys of channel and structure geometry were obtained along the modeled reaches at most structures according to FEMA standards (FEMA, 2011). Field surveys included 15 dams, 91 bridges, and 20 culverts in the Moshassuck and Woonasquatucket River Basins (table 2). As part of the riverine structural surveys, channel and bank profiles, and the approach to and exit from the structures, typically were surveyed. The new survey information also provided accurate georeferencing of the structures in the updated hydraulic models.

The American Recovery and Reinvestment Act of 2009 provided stimulus funding to a consortium of partners for light detection and ranging (LiDAR) mapping for the coastal northeastern U.S. including all of Rhode Island (accessed December 14, 2012, at http://www.neurisa.org/NE_LiDAR_Project). This work was coordinated and contracted through the USGS National Geospatial Technical Operations Center (NGTOC), whose contract specifications meet or exceed FEMA standards for hydraulic analysis (Heidemann, 2012). The NGTOC also provided quality assurance and control of the LiDAR acquisition and interpretation. The LiDAR data provide accurate vertical ground-surface elevation (within $\pm 0.5 \mathrm{ft}$ ) for every pixel nominally spaced every 2 meters $(6.24 \mathrm{ft})$ of land surface in Rhode Island. LiDAR data were not expected to be available for this study, but the data for Rhode Island became available in November 2011 when most of the hydraulic model work was in progress. Accordingly, the USGS, in consultation with FEMA, agreed to expand the scope of the study to utilize the newly available data. Cross sections developed from the LiDAR data are georeferenced in the hydraulic models and provide consistency with the land-surface elevation data that are needed to develop accurate flood inundation maps. The LiDAR data also allow additional cross sections to be added

Table 1. Reaches in the Moshassuck and Woonasquatucket River Basins where detailed hydraulic analyses were done.

[The indentations in column 1 indicate tributaries in decreasing stream order]

\begin{tabular}{lcll}
\hline \multicolumn{1}{c}{ Modeled reaches } & $\begin{array}{c}\text { Reach length } \\
\text { (miles) }\end{array}$ & \multicolumn{1}{c}{ City or town } & County \\
\hline Moshassuck River & 10.1 & Providence, Pawtucket, Lincoln & Providence \\
West River & 4.3 & Providence, North Providence & Providence \\
East Branch West River & .6 & North Providence & Providence \\
Lincoln Downs Brook & 1.0 & North Providence, Lincoln & Providence \\
Upper West Canada Brook & 1.2 & Providence, North Providence & Providence \\
Woonasquatucket River & 15.4 & Providence, North Providence, Johnston, Smithfield & Providence \\
\hline
\end{tabular}


Table 2. Summary of structures surveyed, the number of structures represented, and total number of cross sections in the hydraulic models of the Moshassuck and Woonasquatucket River Basins.

[The indentations in column 1 indicate tributaries in decreasing stream order; total sections, total number of cross sections in the model]

\begin{tabular}{|c|c|c|c|c|c|c|c|}
\hline \multirow[b]{2}{*}{ Reach } & \multicolumn{2}{|c|}{ Dams } & \multicolumn{2}{|c|}{ Bridges } & \multicolumn{2}{|c|}{ Culverts } & \multirow{2}{*}{ Total sections } \\
\hline & Surveyed & Modeled & Surveyed & Modeled & Surveyed & Modeled & \\
\hline Moshassuck River & 2 & 6 & 22 & 26 & 6 & 13 & 377 \\
\hline West River & 3 & 3 & 15 & 15 & 2 & 6 & 189 \\
\hline East Branch West River & 0 & 0 & 0 & 1 & 4 & 6 & 48 \\
\hline Lincoln Downs Brook & 1 & 0 & 1 & 1 & 7 & 7 & 54 \\
\hline Upper Canada Brook & 1 & 2 & 1 & 1 & 1 & 2 & 36 \\
\hline Diversion channel & 0 & 0 & 0 & 0 & 0 & 0 & 16 \\
\hline Woonasquatucket River & 8 & ${ }^{1} 16$ & 52 & 60 & 0 & 4 & 447 \\
\hline Total & 15 & 27 & 91 & 104 & 20 & 38 & 1,167 \\
\hline
\end{tabular}

${ }^{1}$ Three dams were breached.

where distances between the existing cross sections exceed the recommended standards. The cross sections also could be extended to fully incorporate inundated areas that may have been truncated by the limits of the previous cross section. The limitation of the LiDAR data is the channel geometry below the water surface had to be interpolated from previous channel cross-section information except where it was determined by the field surveys made during this study. Future revisions to the hydraulic models should consider updating the in-channel cross-section information.

In anticipation that the updated hydraulic models may be later used as part of FEMAs revisions to the National Flood Insurance Program (NFIP) flood maps, the models have been documented in appendix 1 in a manner similar to FEMA's Technical Support Data Notebook (TSDN) format (FEMA, 2011). The hydraulic models developed for this study were not submitted to the FEMA under the Map Information Product (MIP) system at this time because updates to flood-insurance maps were not directly part of the study.

\section{Flood-Flow Updates}

The flood flows input to the HEC-RAS hydraulic models used in this study were updated from information in the "Magnitude of Floods Flows for Selected Annual-Exceedance Probabilities in Rhode Island through 2010" by Zarriello and others (2012). The flood-frequency report was developed as part of the same FEMA-supported work as this study in response to the 2010 flood. The report updates estimates of flood magnitudes at streamgages and provides regional equations for computing flood magnitudes at ungaged sites for 20-, 10-, 4-, 2-, 1-, 0.5-, and 0.2-percent AEP flows. Methods also were presented to calculate AEP flows at ungaged sites on gaged streams, which were used to estimate flows in the Moshassuck and Woonasquatucket River reaches.
The flood flows used in the latest countywide FIS for Providence (FEMA, 2009) generally are the same as the flows used in the original community FIS, which were determined from methods and information that typically date back to the 1970s. The 10-, 2-, 1-, and 0.2-percent AEP flood flows in the effective FIS report and those computed in this study are summarized in table 3. The effective FIS did not report flows used for the East Branch West River and Lincoln Downs Brook. For other reaches, the locations of specified flows in the FIS and updated models were matched as closely as possible, it was not always apparent if the same location on a reach was used to estimate flows.

Table 3. Comparison of flood insurance study and updated flood flows for selected annual exceedance probabilities in selected reaches in the Moshassuck and Woonasquatucket River Basins, Rhode Island.

[Available separately at http://pubs.usgs.gov/sir/2013/5191/ tables/sir2013-5191_Tables3and4.xlsx]

In the Moshassuck River, at the 1-percent AEP, the updated flows averaged 16 percent less and ranged from 1 to 48 percent less than those reported in the FIS; the greatest differences were at the two most downstream locations (44 and 48 percent less). In the Woonasquatucket River, at the 1-percent AEP, the updated flows also averaged 16 percent less and ranged from 10 to 28 percent less than those reported in the FIS. Flows were determined from streamgage peak-flow records at Moshassuck River at Providence, R.I. (01114000) and Woonasquatucket River at Centerdale, R.I. (01114500); however, the period of record used in the FIS analysis was not specified. Decreases in the updated flows relative to the FIS flows for a given AEP, particularly at the lower exceedance probabilities, were unexpected because the annual peak-flow records at both streamgages indicated an upward trend with 
about a 6 percent slope. In addition, the weighted AEP flows at streamgages were slightly higher than the at-site analysis at both sites-AEP flows at streamgages use a combination of at-site and regional analysis to weight flows inversely proportional to the uncertainty of the estimated values. These factors should result in greater updated AEP flows as compared to the effective FIS flows. The reason why the FIS flows are greater than the updated flows could be caused by the stage-discharge rating stability, skews used in the floodfrequency analysis, and other factors, but the exact cause was not determined.

In the West River, at the 1-percent AEP, the updated flows ranged from 3 to 51 percent less (averaged 44 percent less) than those reported in the FIS. Reported FIS flows (FEMA, 2009) for the West River were determined from TR-20 for the Town of North Providence FIS and from equations developed by Johnston and Laraway (1976) for the City of Providence FIS. These also were the reported methods used to estimate flood flows in the Upper Canada Pond Brook and Lincoln Downs Brook in the respective community FISs, but flow values were not reported in the effective FIS (FEMA, 2009). TR-20 is a rainfall-runoff model used to compute a given AEP flow from the total 48-hour rainfall from TP-40 (U.S. Department of Commerce, 1961) from an equivalent AEP rainfall. The total rainfall is distributed using the SCS type-III distribution (U.S. Department of Agriculture, 1965); however, the FIS is not always clear about the design storm or the distribution type used.

\section{Comparison of 2010 Flood High-Water Marks with Simulated Water Levels}

One of the objectives of this study was to compare the observed 2010 flood HWM elevations to those simulated for similar AEP floods to assess the effective FIS and updated hydraulic models simulated WSEs. HWMs were obtained at 18 sites along the Moshassuck River and 45 sites along the Woonasquatucket River (Zarriello and Bent, 2011; fig. 2). No HWMs were obtained in the tributary reaches to the Moshassuck or Woonasquatucket Rivers.

The 2010 flood HWMs were created from flows estimated to have a 1- to 2-percent AEP on the basis of floodfrequency analysis of the annual-peak flows, weighted with the regional flood-flow equations at streamgages in the basins. The 2010 peak flow at Moshassuck River at Providence, R.I. (01114000), was estimated to have about a 1-percent AEP (Zarriello and others, 2012; table 17) - the recorded peak $\left(2,040\right.$ cubic feet per second $\left(\mathrm{ft}^{3} / \mathrm{s}\right)$ is about 2 percent less than the updated 1-percent AEP flow $\left(2,080 \mathrm{ft}^{3} / \mathrm{s}\right)$ at the streamgage. The 2010 peak flow at Woonasquatucket River at Centerdale, R.I. (01114500), was estimated to have about a 2-percent AEP - the recorded peak $\left(1,750 \mathrm{ft}^{3} / \mathrm{s}\right)$ was about 1 percent greater than the updated 2-percent AEP flow $\left(1,730 \mathrm{ft}^{3} / \mathrm{s}\right)$ at the streamgage. The effective FIS flow at the 1- and 2-percent AEP at the Moshassuck and Woonasquatucket River streamgages were about 61 and 24 percent greater than the recorded 2010 peak peaks, respectively.

Although the observed 2010 peak flows at the streamgages do not match exactly the equivalent AEP flows used in the effective FIS and the updated models, the simulated WSE at their respective AEP flow in the effective FIS and the updated models provide a common basis from which WSEs for similar AEP floods can be compared. While the 2010 peak flows could be simulated to directly compare differences in the WSE and the HWMs, this can be done only where peak-flow data are available or could be reasonably estimated from streamgage records. Given the limited extent of known 2010 peak flows, the models were not adjusted to better match simulated and observed water levels.

It should be noted that the simulated WSEs were determined on the basis of unobstructed flow from debris and the simulated WSE is considered valid only if structures and the stream channel remain clear. During field reconnaissance, field surveys, and review of photographs obtained from the WEB this condition does not always appear to be true; a lower simulated WSE would be expected compared to the observed 2010 HWM elevations when obstructions are present. It also should be noted that the quality of HWMs vary and are subject to uncertainty.

In the Moshassuck River, the updated HEC-RAS flows at the 1-percent AEP, on average, were 16 percent less than the effective FIS flows. Correspondingly, the updated model WSEs, on average, were about $0.6 \mathrm{ft}$ lower than the FIS WSEs at the HWM locations. In comparison to the 2010 HWM elevations, the updated model WSEs at the 1-percent AEP flow, on average, were about $0.6 \mathrm{ft}$ higher with differences ranging from about -4.8 to $4.2 \mathrm{ft}$ (table 4 , fig. 3 ). The effective FIS WSEs at the 1-percent AEP flows, on average, were about $1.2 \mathrm{ft}$ higher than the HWM elevations with differences ranging from about -3.9 to $4.7 \mathrm{ft}$. The overall difference, as measured by the standard deviation between the HWMs and the simulated WSEs, were slightly less for the effective FIS $(2.14 \mathrm{ft})$ than for the updated model $(2.41 \mathrm{ft})$, which also is indicated in the boxplot in figure 4 .

In the Moshassuck River, the greatest differences between the HWMs and the simulated WSEs were near the mouth between Mill and Smith Streets (stations 2,239 and 2,499); the HWMs were 4.8 and $3.2 \mathrm{ft}$ higher than the updated model WSEs, respectively. This indicates debris (not simulated in the model) at the downstream bridge at Smith Street may have affected the WSEs in this reach. Also, the operation of the FPHB during the peak of the 2010 flood could have caused the actual WSE at the mouth of the Moshassuck River to be higher than the specified starting WSE in the model. The starting WSE in the lower part of the river was set to the maximum reported WSE on the riverine side of the barrier $(9.29 \mathrm{ft}$ NAVD 88; Larry Davis, U.S. Army Corps of Engineers, written commun., July 5, 2011), but continuous stage records were not available to determine if this was the actual peak stage behind the barrier during the 2010 flood. 


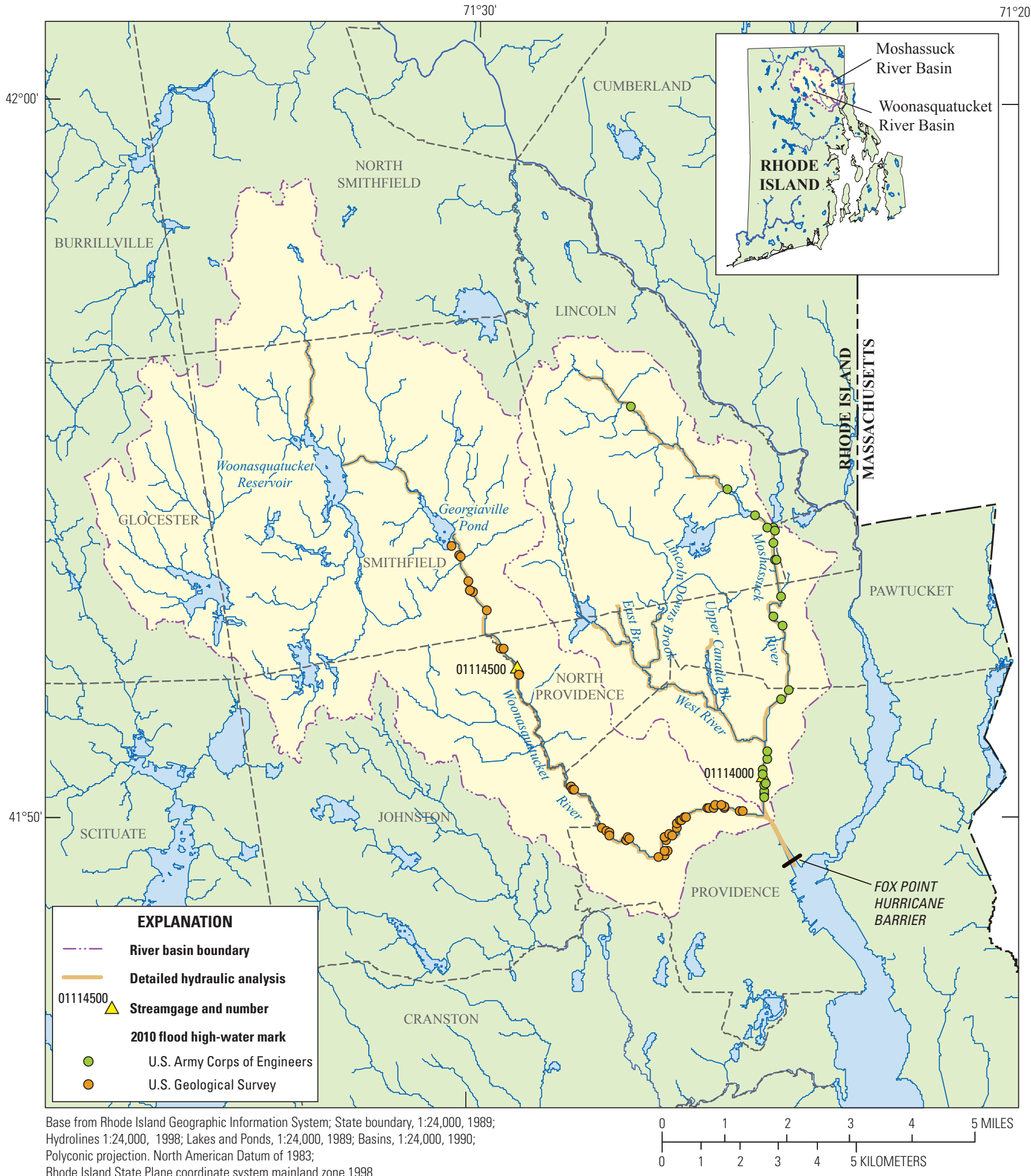

Figure 2. High-water marks obtained after the 2010 flood along reaches of detailed hydraulic analysis in the Moshassuck and Woonasquatucket Rivers, Rhode Island. 
Table 4. Comparison of the 2010 flood high-water mark (HWM) elevations to the effective flood insurance study (FIS) and updated hydraulic model water-surface elevations at the 1-percent annual exceedance probability (AEP) in the Moshassuck River and the 2-percent AEP in the Woonasquatucket River, Rhode Island.

[Available separately at http://pubs.usgs.gov/sir/2013/5191/ tables/sir2013-5191_Tables3and4.xlsx]

Large differences between the simulated and observed WSE in the Moshassuck River also were noted upstream of Mineral Spring Avenue (station 18,853). The FIS and updated model WSEs were about $4 \mathrm{ft}$ higher than the observed HWM elevation, indicating the HWM may have been from a pause in the recession and not the peak. Differences between simulated and observed WSEs at other locations also could be attributed to false peaks or other causes. No information is available on the quality of the HWM or the experience of those setting the HWMs along the Moshassuck River.
In the Woonasquatucket River, the 2010 peak flow at the streamgage at Centerdale, R.I. (011114500), was about equal to the updated 2-percent AEP flood flow (1,750 and 1,720, respectively). On average, the updated 2-percent AEP flow was about 13 percent less than the effective FIS flow over the reach (table 3). As a result, the updated model WSE is about $0.5 \mathrm{ft}$ lower, on average, than the FIS elevations at the 44 HWM locations. The updated model WSEs averaged about $1.6 \mathrm{ft}$ lower than the HWM elevations with differences ranging from about -5.4 to $0.6 \mathrm{ft}$ (table 4, fig. 3). The effective FIS WSEs averaged $1.1 \mathrm{ft}$ lower than the HWM elevations with differences ranging from about -5.6 to $3.4 \mathrm{ft}$. The differences between the HWMs and the simulated WSEs, as measured by the standard deviation, are less variable in the updated model $(1.41 \mathrm{ft})$ than for the effective FIS model $(1.89 \mathrm{ft})$, which also is indicated in the boxplots in figure 4 .

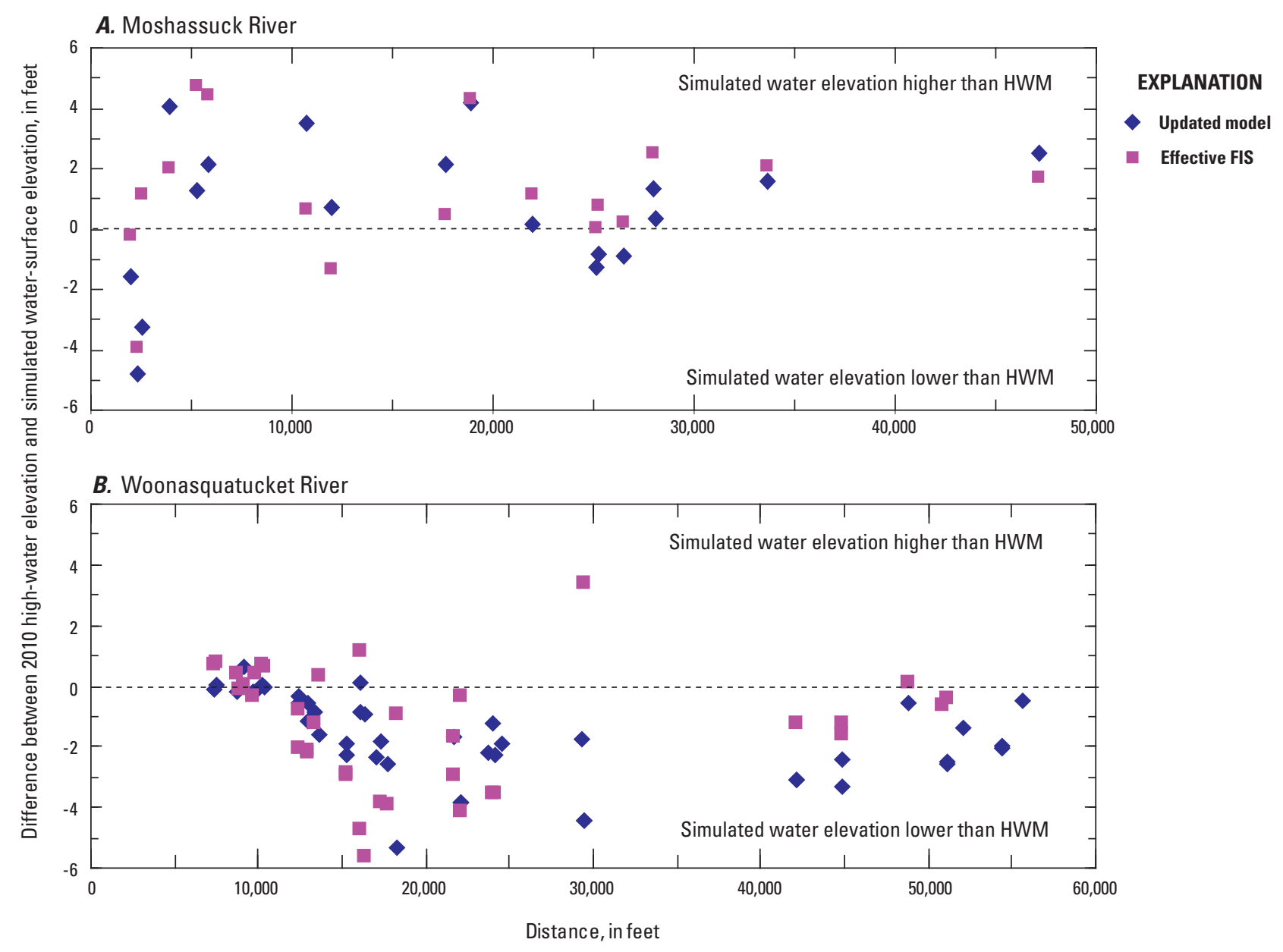

Figure 3. The difference between the 2010 flood high-water mark (HWM) elevations and water-surface elevations from the effective flood insurance study (FIS) and updated hydraulic model. $A$, 1-percent annual exceedance probability (AEP) in the Moshassuck River. B, 2-percent AEP in the Woonasquatucket River, Rhode Island. 


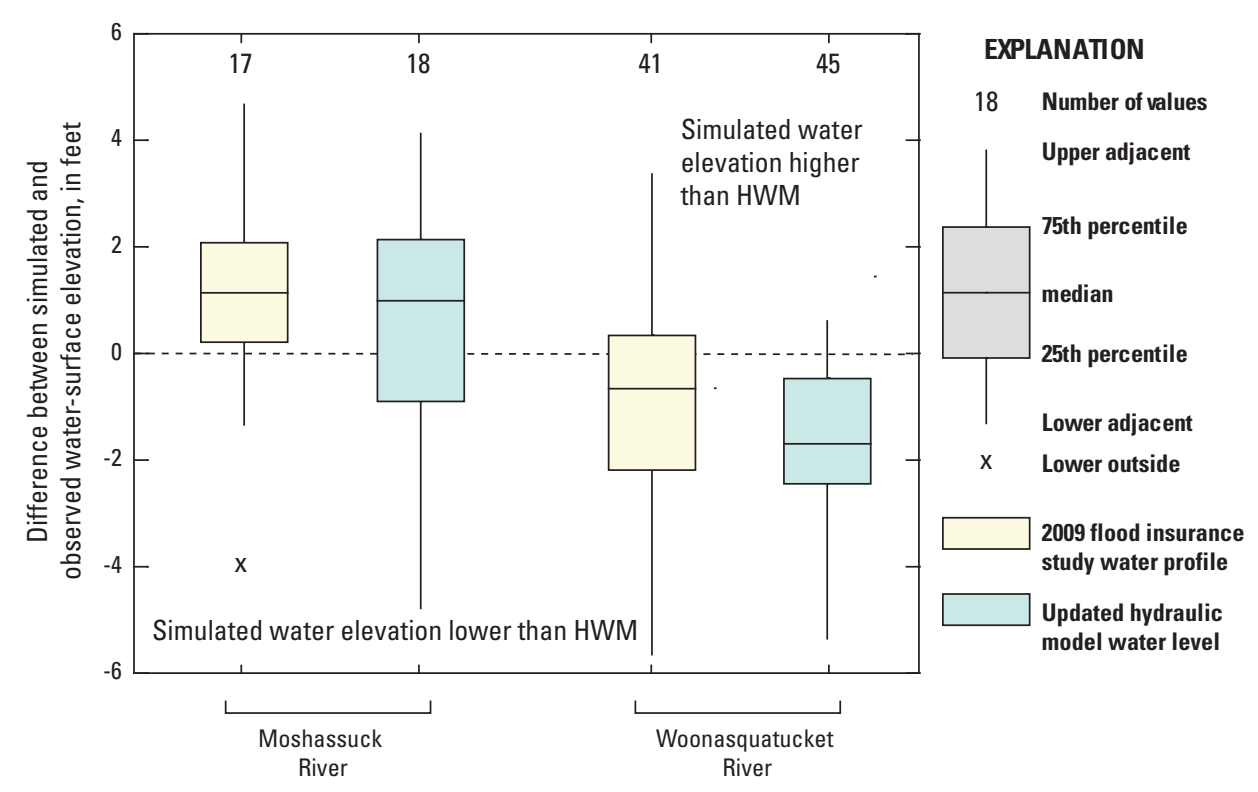

Figure 4. Differences between the 2010 flood high-water mark (HWM) elevations and water-surface elevations from the effective flood insurance study (FIS) and updated hydraulic models at the 1-percent annual exceedance probability (AEP) in the Moshassuck River and at the 2-percent AEP in the Woonasquatucket River, Rhode Island.
At the 2-percent AEP flow, the Woonasquatucket River 2010 flood HWM elevations generally are higher than the FIS and the updated model WSEs. The greatest difference was at Manton Avenue where the $2010 \mathrm{HWM}$ was about 5.4 and $4.8 \mathrm{ft}$ higher than the updated model and FIS WSE, respectively. The HWM was rated poor and the mark was upstream of a bridge, which could have been affected by debris. The updated model WSEs also were appreciably lower than the HWM elevations at the upstream side of Greenville Street (4.4 ft), Route 6 (3.8 ft), Greystone Avenue (3.3 ft), and Route 44 (3.1 ft), which also indicate debris may have affected the HWM elevations. Water elevations in the effective FIS at these locations (where available) also were appreciably lower than the HWM elevations, but generally not as low as updated model WSEs because of the higher discharge used in the effective FIS model. The simulated WSEs are lower than the HWMs elevations at most other locations indicating that the magnitude of the 2010 peak may be greater than a 2-percent AEP flow in the Woonasquatucket River or the river conveyance capacity may be less than simulated, or both. If the HWMs upstream of bridges at the sites listed above were excluded, the updated model WSEs would average about $1.1 \mathrm{ft}$ less than the remaining HWM elevations; the maximum difference is $2.6 \mathrm{ft}$ less and the differences between simulated and observed WSEs are better balanced around the line of equality (zero). This indicates that the model hydraulic representation and flows, on the whole, are reasonable and the temporary constriction from debris and increased friction losses (Manning's " $n$ " roughness values) could explain differences between the simulated and 2010 WSEs. Without additional information, changes to the model do not appear to be warranted at this time.
The previous comparisons were made on the basis of the best estimate of the AEP flow. Estimated flows for a given AEP can vary appreciably within the 95-percent confidence interval as determined from streamgage-record analysis or regionalized flood-flow equations, or both. The upper confidence interval is often 2 to 3 times the best estimated value for a given AEP. The uncertainty of the flood magnitude for any given AEP should be considered in the application of the WSEs for a given flow probability.

\section{Example Map of 2010 Flood Inundation}

The updated hydraulic model was used to construct an example map of the 2010 flood-inundated areas and the depth of flooding on the basis of the 1- and 2-percent AEP flow in the Moshassuck and Woonasquatucket Rivers, respectively. As previously noted, these AEP flows are the estimated magnitude of the 2010 flood. The example inundation map (fig. 5) at the 2-percent AEP for the Woonasquatucket River shows flooding along Valley Street in Providence, R.I., where the photograph in figure 6 was taken. The simulated water depth (about 3.1 to $3.5 \mathrm{ft}$ ) corresponds to the water depth around the partially submerged automobile shown in the photograph.

The flood inundation map depth is determined by the HEC-RAS simulated water elevations at each cross section and extrapolated between cross sections to develop a gridded water elevation map from which the LiDAR land surface grid is subtracted. The resulting grid indicates the depth of flooding for each pixel within the inundated area. Inundation maps are designed to work interactively within a geographic 


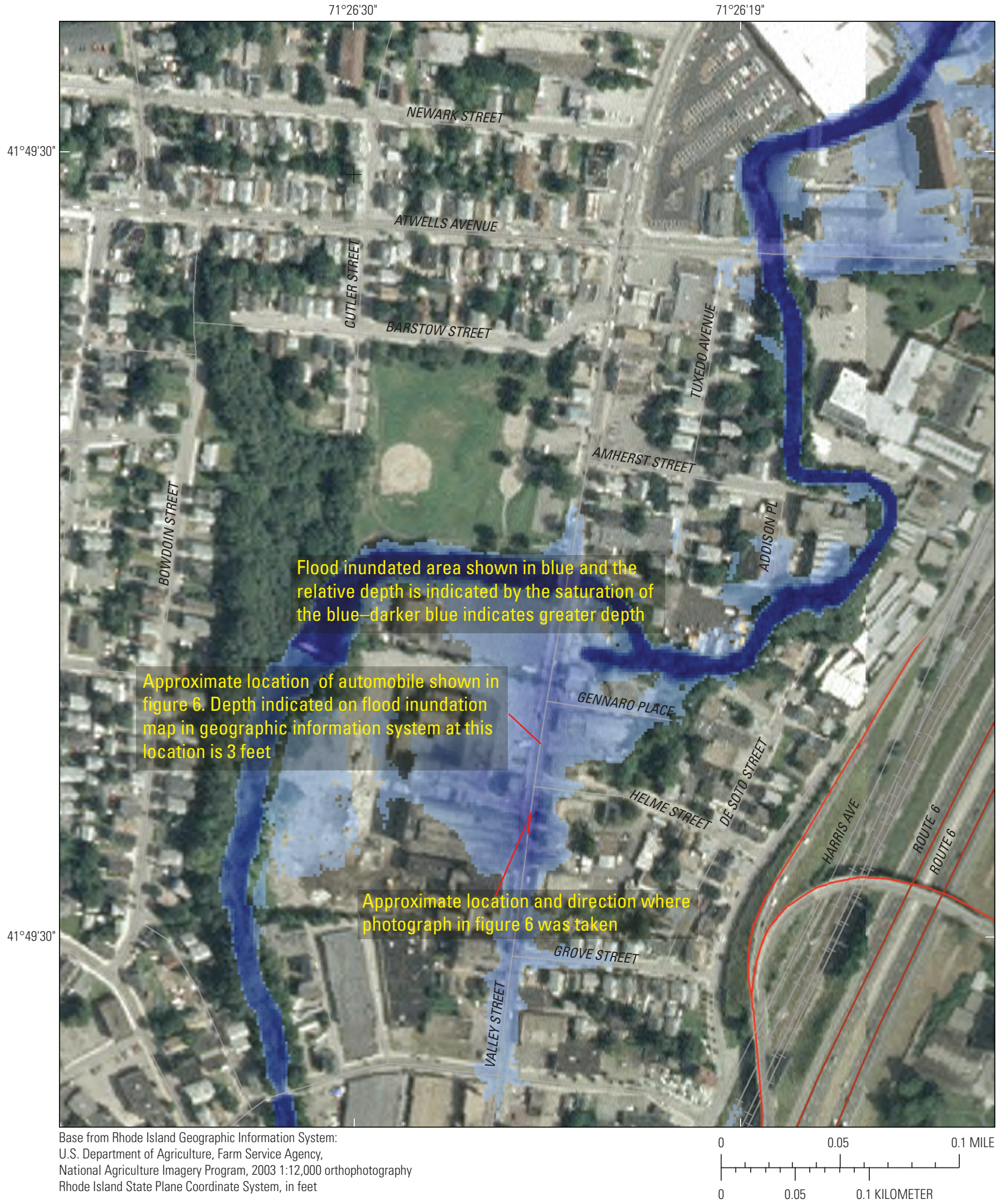

Figure 5. Flood inundation at the 2-percent annual exceedance probability along the Woonasquatucket River at Valley Street in Providence, Rhode Island, where the photograph in figure 6 was taken. 


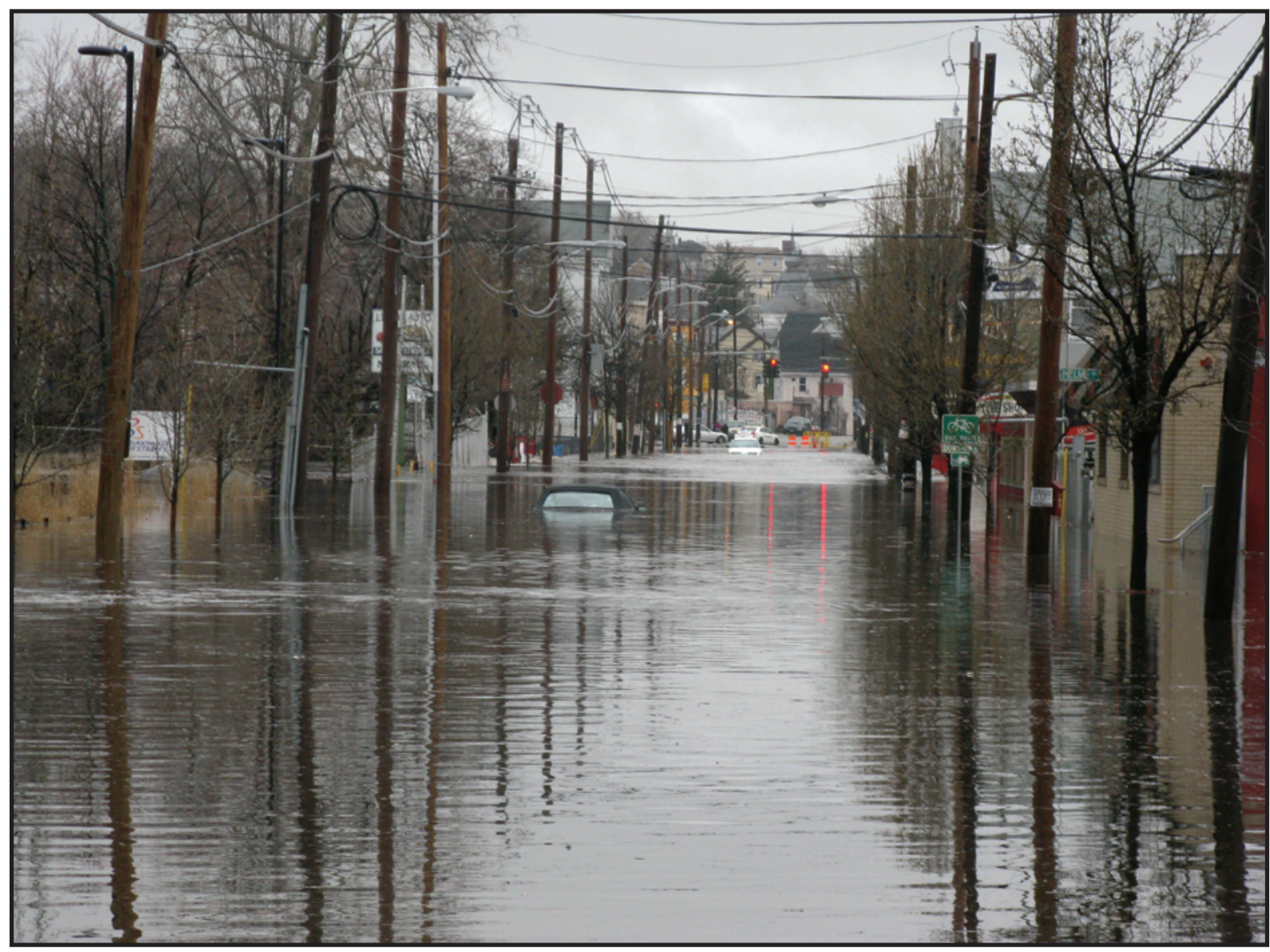

Figure 6. Woonasquatucket River flooding on Valley Street looking toward Atwells Avenue, Providence, Rhode Island.

information system, which can focus to an area of interest to examine flooding at specific locations.

The hydraulic models developed during this study could be used to develop maps of incremental flood inundation over a range of flows and corresponding stream stages in the reaches near streamgages. Incremental flood-inundation maps provide information on the area inundated at various flood magnitudes and could be incorporated into a Web-based map interface such as the USGS Flood Inundation Mapping Science Web site (http://water.usgs.gov/osw/flood_inundation/), which is designed to help communicate where flooding occurs. Whether a flood map is indexed to a USGS streamgage or just to a flood magnitude, the information can be used to assess flood risk and help plan for future flood events. For purposes of this investigation, however, only the magnitude of the 2010 flood was examined.

In this type of map, inundated areas as shown on figure 5 are for planning purposes only and are not intended for regulatory, permitting, or other legal purposes. The USGS provides these maps "as-is" for a quick reference, emergency planning tool but assumes no liability or responsibility from the use of this information. The actual inundated area and depth of water during the 2010 flood may differ from that shown because of debris, model error, or elevation-data inadequacies.

\section{Summary and Conclusions}

On March 30, 2010, an Emergency Declaration was declared for Rhode Island (Rhode Island Severe Storms and Flooding (EM-3311), http://www.fema.gov/disasters/3311), following heavy persistent rains from late February through March 2010. The rainfall caused severe flooding and set, or nearly set, record high streamflows and water levels at many long-term streamgages in the state. In August 2010, the U.S. Geological Survey (USGS) entered into an agreement with the U.S. Department of Homeland Security-Federal Emergency Management Agency (FEMA) to document and characterize the March-April 2010 flood. As part of that agreement, hydraulic models in selected river reaches of the Moshassuck and Woonasquatucket River Basins were 
updated to simulate water-surface elevations (WSEs) from specified flows, boundary conditions, and the reach carrying capacity or conveyance. The updated models, along with previously developed models for flood insurance studies (FISs), were evaluated in comparison to high-water mark (HWM) elevations obtained following the March-April 2010 flood in a related USGS-FEMA study. Hydraulic models are an important tool for flood-plain management, transportation infrastructure design, flood insurance studies, and other purposes to help minimize future flood damages and risks.

The Moshassuck and Woonasquatucket River Basins cover an area of about 24 and 51 square miles, respectively, in north-central Rhode Island. Hydraulic models were developed for about 17.2 miles (mi) of the Moshassuck River and four tributary reaches, and about $15.4 \mathrm{mi}$ of the Woonasquatucket River. The two rivers converge to form the Providence River in the City of Providence about 0.9 mi upstream of the Fox Point Hurricane Barrier at the north end of Narragansett Bay. The Providence River was simulated as part of the Woonasquatucket River hydraulic model. Tributaries to the Moshassuck River include the West River and three of its tributaries-East Branch West River, Lincoln Downs Brook, and Upper Canada Brook.

The hydraulic models were updated to Hydrologic Engineering Center-River Analysis System (HEC-RAS) version 4.1.0 for steady-state simulations. Flows at the $10-, 2-, 1-$, and 0.2 -percent annual exceedance probability (AEP) floods for gaged and ungaged sites were updated in the hydraulic models from the results and methods reported by Zarriello and others (2012). Updates also included field surveys at structures including 28 dams, 104 bridges, and 38 culverts along the modeled reaches. Additional crosssection information was obtained from recently acquired light detection and ranging (LiDAR), which provides accurate landsurface elevation data.

The flood flows used in the effective FIS (Providence County, done in 2009) generally are the same as those used in the original community FIS from the 1970s, which were determined from a variety of methods depending upon when and who did the analysis. The updated AEP flows used in this study on gaged reaches (Moshassuck and Woonasquatucket Rivers) averaged 16 percent less than the flows used in the effective FIS. Flows for the upper West River, determined by the TR-20 rainfall-runoff model and a 48-hour rainfall corresponding to the same AEP in the effective FIS, are about twice as large as the updated AEP flows. In the lower West River and in the lower Upper Canada Brook, the effective FIS flows were determined by regional-regression equations for small streams in Rhode Island, which were developed in 1976. In the East Branch West River and Lincoln Downs Brook, flows were not reported in the effective FIS.

HWMs from the 2010 flood were obtained at 18 sites along the Moshassuck River and at 45 sites along the Woonasquatucket River. The 2010 flood is estimated to have an AEP of about 1- and 2-percent in the Moshassuck and Woonasquatucket River Basins, respectively. The HWM elevations were compared to the effective FIS WSEs and updated HEC-RAS simulated WSEs in this study for the equivalent AEP floods in the respective basins. The FIS and updated WSEs were not appreciably different but did differ appreciably from the 2010 HWM elevations. In the Moshassuck River, the simulated WSEs generally were higher than the 2010 HWM elevations at the 1-percent AEP flow. In the Woonasquatucket River, the simulated WSEs generally were lower than the $2010 \mathrm{HWM}$ elevations at the 2-percent AEP flow. The differences between the 2010 HWM elevations and simulated WSEs could be attributed to debris and other factors; therefore, major changes to the updated hydraulic models were not made.

The hydraulic models developed in this study did not produce appreciably different results from the effective FIS WSEs as measured by the differences in the 2010 HWM elevations. The updated models, however, better represent current conditions and are consistent with high-resolution digital land-surface elevation data. This study provides an assessment of the model for consideration in delineations of flood zones, flood-plain management operations, infrastructure design, and other purposes.

\section{References Cited}

Brunner, G.W., 2010a, HEC-RAS river analysis system, user's manual (version 4.1): Davis, Calif., U.S. Army Corps of Engineers, Hydrologic Engineering Center, CPD-68, 766 p.

Brunner, G.W., 2010b, HEC-RAS river analysis system, hydraulic reference manual (version 4.1): Davis, Calif., U.S. Army Corps of Engineers, Hydrologic Engineering Center, CPD-69, 411 p.

FEMA - Federal Emergency Management Agency

FEMA, 1974, Flood Insurance Study, Town of North Providence: community no. 440020 , prepared by the U.S. Department of Agriculture, Soil Conservation Service for the U.S. Department of Housing and Urban Development, Federal Insurance Administration, 15 p.

FEMA, 1982, Flood Insurance Study, Town of Lincoln: community no. 445400 , prepared by Harris-Toups Associates for the U.S. Department of Housing and Urban Development, Federal Insurance Administration, 35 p.

FEMA, 1983, Flood Insurance Study, City of Providence: prepared by P.R.C. Harris, Boston, Mass., for the Federal Emergency Management Agency, Division of Insurance and Mitigation, $43 \mathrm{p}$.

FEMA, 1999, Flood Insurance Study, Town of North Providence, Providence County, Rhode Island: community no. $440020,34 \mathrm{p}$. 
FEMA, 2009, Flood Insurance Study, Providence County, Rhode Island (all jurisdictions); no. 44007CV001A, 3 v., $262 \mathrm{p}$.

FEMA, 2011, Guidelines and standards for flood hazard mapping partners, Appendix M: Data capture standards, $170 \mathrm{p}$.

Heidemann, H.K., 2012, Lidar base specification version 1.0: U.S. Geological Survey Techniques and Methods, book 11, chap. B4, 63 p. (available at http://pubs.usgs.gov/tm/11b4/.)

Johnson, C.G., and Laraway, G.A., 1976, Flood magnitude and frequency of small Rhode Island streams: preliminary estimating relations: U.S. Geological Survey Open-File Report 76-883, 20 p.

U.S. Army Corps of Engineers, Hydrologic Engineering Center, 1991, HEC-2 Water surface profiles user's manual: Davis, Calif., U.S. Army Corps of Engineers, Hydrologic Engineering Center, 334 p.

U.S. Department of Agriculture, 1965, Computer program for project formulation-Hydrology: Washington, D.C., Soil Conservation Service, Engineering Division, Technical Release 20, 294 p.
U.S. Department of Agriculture, 1976, WSP-2 computer program: Washington, D.C., Soil Conservation Service, Engineering Division, Technical Release No. 61, 51 p.

U.S. Department of Commerce, 1961, Rainfall frequency atlas of the United States for durations from 30 minutes to 24 hours and return periods from 1 to 100 years: Washington, D.C., Weather Bureau, Technical Paper No. 40, 61 p.

U.S. Interagency Advisory Committee on Water Data, 1982, Guidelines for determining flood flow frequency: Reston, Va., U.S. Geological Survey, Office of Water Data Coordination, Bulletin 17B of the Hydrology Subcommittee, $183 \mathrm{p}$.

Zarriello, P.J., Ahearn, E.A., and Levin, S.B., 2012, Magnitude of flood flows for selected annual exceedance probabilities in Rhode Island through 2010: U.S. Geological Survey Scientific Investigations Report 2012-5109, 93 p. (available at http://pubs.usgs.gov/sir/2012/5109/)

Zarriello, P.J., and Bent, G.C., 2011, Elevation of the MarchApril 2010 flood high water in selected river reaches in Rhode Island: U.S. Geological Survey Open-File Report 2011-1029, 34 p. (available at http://pubs.usgs.gov/ ofr/2011/1029/) 
THIS PAGE INTENTIONALLY LEFT BLANK 


\title{
Appendix 1. Moshassuck and Woonasquatucket River Basin Hydraulic Models: Technical Data Support Notebook
}

\author{
The hydraulic models developed in this study may be used to update Digital Flood Insurance \\ Rate Map (DFIRM) by the U.S. Department of Homeland Security-Federal Emergency Manage- \\ ment Agency (FEMA), but have not been approved for that purpose. As such, modifications to \\ the models described in this report may be made prior to DFIRM production.
}




\section{Background}

Following severe flooding during March-April 2010, the U.S. Geological Survey (USGS) and the U.S. Department of Homeland Security-Federal Emergency Management Agency (FEMA) entered into an agreement to characterize the hydrology and hydraulics of selected river reaches in parts of Rhode Island. In this study, hydraulic models of the Moshassuck and Woonasquatucket River Basins were updated to Hydrologic Engineering Center-River Analysis System (HEC-RAS) version 4.1.0 (table 1-1). Updates to the models included field surveys made at structures along the modeled reaches; incorporation of high-resolution landsurface elevation data (LiDAR) acquired in November 2011; conversion of existing hydraulic-model information, where needed; and updated flood flows at gaged and ungaged sites from a recent related study.

Reaches selected for detailed hydraulic analysis in the Moshassuck and Woonasquatucket River Basins in this study were determined jointly by FEMA and the Rhode Island Emergency Management Agency. The Moshassuck
River, Woonasquatucket River, and four tributary reaches to the Moshassuck River were identified for updated analysis. Tributaries to the Moshassuck River included the West River, East Branch West River, Lincoln Downs Brook, and Upper Canada Pond Brook; the last three are tributaries to the West River (fig. 1).

The updated hydraulic models were developed by the USGS for FEMA under Interagency Agreement number HSFEHQ-10-X-0672. The agreement began August 11, 2010, and ended March 30, 2013.

\section{Scope of Work}

The Technical Support Data Notebook (TSDN) includes details about the hydraulic model for selected reaches in the Moshassuck and Woonasquatucket River Basins in Providence County, Rhode Island. The reaches include the Moshassuck River, West River, East Branch West River, Lincoln Downs Brook, Upper Canada Pond Brook, and Woonasquatucket River. A single model was developed for reaches in the

Table 1-1. Summary of updated hydraulic model reaches in the Moshassuck and Woonasquatucket River Basins and flood insurance study (FIS) for the reach.

[Effective FIS date is the countywide FIS report which supersedes all previous community FIS reports]

\begin{tabular}{|c|c|c|c|}
\hline Reach name & FIS date & Community & Community number \\
\hline \multicolumn{4}{|c|}{ Effective (2013) FIS } \\
\hline All reaches & 2009 & Providence County, all jurisdictions & 44007 \\
\hline \multicolumn{4}{|c|}{ Superseded community studies } \\
\hline \multirow[t]{3}{*}{ Moshassuck River } & $1970,1975,1976,1986,2000$ & City of Providence & 445406 \\
\hline & 1971, 1974, 1976, 1982, 1986 & City of Pawtucket & 440022 \\
\hline & $1973,1974,1975,1982$ & Town of Lincoln & 445400 \\
\hline \multirow[t]{2}{*}{ West River } & $1970,1975,1976,1986,2000$ & City of Providence & 445406 \\
\hline & 1977, 1993, 1999 & Town of North Providence & 440020 \\
\hline East Branch West River & 1977, 1993, 1999 & Town of North Providence & 440020 \\
\hline \multirow[t]{2}{*}{ Lincoln Downs Brook } & 1977, 1993, 1999 & Town of North Providence & 440020 \\
\hline & $1973,1974,1975,1982$ & Town of Lincoln & 445400 \\
\hline \multirow[t]{2}{*}{ Upper Canada Pond Brook } & $1970,1975,1976,1986,2000$ & City of Providence & 445406 \\
\hline & 1977, 1993, 1999 & Town of North Providence & 440020 \\
\hline \multirow[t]{3}{*}{ Woonasquatucket River } & $1970,1975,1976,1986,2000$ & City of Providence & 445406 \\
\hline & 1978,1993 & Town of Johnston & 440018 \\
\hline & 1977, 1991 & Town of Smithfield & 440021 \\
\hline
\end{tabular}


Moshassuck River Basin, which includes the main stem, West River, East Branch West River, Lincoln Downs Brook, Upper Canada Pond Brook, and an overflow diversion from the West River. The Woonasquatucket River model does not include any tributary reaches.

\section{Moshassuck River}

The Moshassuck River model begins at its confluence with the Woonasquatucket River in the City of Providence and ends about 10 miles (mi) upstream at the outlet of Limerock Reservoir in the Town of Lincoln (fig. 1). The lower part of the river runs through the Cities of Pawtucket and Providence.

\section{West River}

The West River is the largest tributary to the Moshassuck River and is included as a separate reach in the Moshassuck River model. The West River model begins at its confluence with the Moshassuck River in the City of Providence and ends about $4.3 \mathrm{mi}$ upstream at the outlet of Wenscott Reservoir in the Town of North Providence (fig. 1). A railroad corridor about 1,700 feet (ft) upstream of the mouth of the West River acts as an overflow conduit during high flow, which prior to the construction of a diversion conduit flowed into the Woonasquatucket River. The diversion conduit now channels the flow from the railroad corridor back into the Moshassuck River about 4,800 ft downstream of the West River, about $1,400 \mathrm{ft}$ above its confluence with the Woonasquatucket River.

\section{East Branch West River}

The East Branch West River is a tributary to the West River, which starts at its mouth in the Town of North Providence and ends about $0.6 \mathrm{mi}$ upstream near the boundary of the towns of Lincoln and North Providence (fig. 1). The confluence of the East Branch West River is about 3.5 mi upstream of the mouth of the West River with the Moshassuck River.

\section{Lincoln Downs Brook}

Lincoln Downs Brook is a tributary to the West River, which starts at its mouth in the Town of North Providence and ends about $1 \mathrm{mi}$ upstream in the Towns of Lincoln (fig. 1). The confluence of the Lincoln Downs Brook is about 2.7 mi upstream of the mouth of the West River with the Moshassuck River.

\section{Upper Canada Pond Brook}

Upper Canada Pond Brook is a tributary to the West River, which starts at its mouth in the City Providence and ends about 1.2 mi upstream in the Town of North Providence (fig. 1). The confluence of the Upper Canada Pond Brook is about 1.1 mi upstream of the mouth of the West River with the Moshassuck River.

\section{Woonasquatucket River}

The Woonasquatucket River model begins at the Fox Point Hurricane Barrier in the City of Providence and ends about 15 mi upstream, about 1 mi upstream of the Woonasquatucket Reservoir in the Town of Smithfield (fig. 1). The river is bordered by the towns of North Providence and Johnston. At the confluence with the Moshassuck River, about 0.9 mi upstream of the hurricane barrier, the river is known as the Providence River, but was considered part of the Woonasquatucket River for purposes of this study.

\section{Engineering Analyses}

The engineering analyses include hydrologic and hydraulic analyses. The hydrologic analysis provides the magnitude of flood flows specified in the hydraulic models. The hydraulic analysis is the development of the hydraulic model used to simulate the water-surface elevation (WSE) for a specified flood flow.

\section{Hydrologic Analyses}

Most hydrologic analyses used in this study were determined from updated annual exceedance probability (AEP) flood flows at streamgages and the regional floodflow equations for ungaged streams developed in a related USGS-FEMA study by Zarriello and others (2012). Flows at streamgages for 10-, 2-, 1-, and 0.2-percent AEP floods were determined by the standard log-Pearson type-III method described in Bulletin 17B of the Hydrology Subcommittee (U.S. Interagency Advisory Committee on Water Data, 1982) and a modification of this method called the expected moments algorithm (EMA). The regional flood-flow equations developed from the at-site analysis were used to estimate flood flows at ungaged sites in the Moshassuck and Woonasquatucket River Basins. The report by Zarriello and others (2012) provides equations for adjusting flood flows at ungaged sites on gaged streams, which were used for estimating flows in the Moshassuck and Woonasquatucket Rivers when the ungaged sites were within \pm 50 percent of the drainage area of the streamgage.

Flows specified in HEC-RAS are used in the model from upstream to downstream until a new flow is specified. Specified flows typically were determined at transition points where the drainage area changes appreciably, such as at the confluence with a large tributary. For example, the flow in the reach above the tributary would be determined from the drainage area just above the confluence and used as the flow in the reach until the next large tributary. The process would repeat 
until representative flows are determined for the model reach. The drainage area reported in the tables that follow were generally determined at the downstream end of the reach where the flow applies, as described above; however, the cross section (and description) specified in each of the reach tables is at the upstream end of the reach where the flow is first specified.

\section{Moshassuck River}

Flows specified for the Moshassuck River were determined from the streamgage at Providence, R.I. (01114000), annual peak flow records for 1963-2010 and extended records from 1942-62 weighted by flow determined with the regional-regression equations (Zarriello and others, 2012). Discharges within about \pm 50 percent of the drainage area of the streamgage (table 1-2) were adjusted from the gaged location using a drainage area ratio method by Sauer (1974). Discharge at locations with drainage areas from 7.2 to $10.9 \mathrm{mi}^{2}$ were determined with the regional-regression equations (Zarriello and others, 2012). Discharges at locations less than $7.2 \mathrm{mi}^{2}$ were determined by a simple drainage area ratio adjustment of discharges determined by the regional regression equations at the $7.2 \mathrm{mi}^{2}$ drainage area.

\section{West River}

Flows specified for the West River (table 1-3) were determined from regional-regression equations (Zarriello and others, 2012). During high flows, water levels in the West River rise enough that some flow is diverted down a railroad right-of-way about $0.26 \mathrm{mi}$ above its confluence with the Moshassuck River. This diverted flow is simulated in the HEC-RAS model by a reach referred to as "Amtrak ROW" and the flow in this reach was computed by the HECRAS model using the "flow optimization" option. The flow optimization was run once, and the computed flows then were specified as the flows in the diversion channel.

\section{East Branch West River, Lincoln Downs Brook, and Upper Canada Pond Brook}

Flows specified for the East Branch West River, Lincoln Downs Brook, and Upper Canada Pond Brook (table 1-4) were determined from the difference in the flows determined above and below the confluence with the West River by the regional-regression equations. This method was used because the drainage areas for these reaches were outside the applicable range of the regional-regression equations. The method also ensured a mass balance of flows at the confluence.

Table 1-2. Annual exceedance probability flows specified in the hydraulic model for the Moshassuck River, Rhode Island.

$\left[\mathrm{mi}^{2}\right.$, square mile; fts $/ \mathrm{s}$, cubic feet per second; USGS, U.S. Geological Survey]

\begin{tabular}{|c|c|c|c|c|c|c|c|}
\hline \multirow[t]{2}{*}{ Description } & \multicolumn{2}{|c|}{ Cross section station } & \multirow{2}{*}{$\begin{array}{c}\text { Drainage } \\
\text { area }^{1} \\
\left(\mathrm{mi}^{2}\right)\end{array}$} & \multicolumn{4}{|c|}{$\begin{array}{l}\text { Discharge }\left(\mathrm{ft}^{3} / \mathrm{s}\right) \text { for specified percent } \\
\text { annual exceedance probability }\end{array}$} \\
\hline & From & To & & 10 & 2 & 1 & 0.2 \\
\hline Uppermost cross section & 53,145 & 50,160 & 0.75 & 40 & 70 & 80 & 110 \\
\hline Culvert beneath Route 146 & 50,093 & 47,161 & 1.2 & 60 & 110 & 130 & 190 \\
\hline Sherman Avenue bridge & 47,128 & 42,460 & 3.0 & 160 & 270 & 320 & 460 \\
\hline Below confluence with Olney Pond outlet & 30,973 & 24,886 & 7.2 & 380 & 640 & 760 & 1,090 \\
\hline Below confluence with Spectacle Pond outlet & 24,272 & 18,795 & 8.0 & 420 & 700 & 840 & 1,200 \\
\hline Below Mineral Spring Avenue & 18,776 & 15,971 & 8.9 & 490 & 840 & 1,000 & 1,440 \\
\hline Below upstream end of culvert I-95 & 15,517 & 9,754 & 10.1 & 580 & 990 & 1,180 & 1,710 \\
\hline
\end{tabular}

${ }^{1}$ The drainage area is the downstream point ("To" station) where the flow was determined; the "From" station and "Description" is the upstream point where the flow is first specified. 
Table 1-3. Annual exceedance probability flows specified in the hydraulic model for the West River, Rhode Island.

$\left[\mathrm{mi}^{2}\right.$, square mile; $\mathrm{ft}^{3} / \mathrm{s}$, cubic feet per second; --, not applicable]

\begin{tabular}{|c|c|c|c|c|c|c|c|}
\hline \multirow[t]{2}{*}{ Description } & \multicolumn{2}{|c|}{ Cross section station } & \multirow{2}{*}{$\begin{array}{c}\text { Drainage } \\
\text { area }^{1} \\
\left(\mathrm{mi}^{2}\right)\end{array}$} & \multicolumn{4}{|c|}{$\begin{array}{c}\text { Discharge }\left(\mathrm{ft}^{3} / \mathrm{s}\right) \text { for specified percent annual } \\
\text { exceedance probability }\end{array}$} \\
\hline & From & To & & 10 & 2 & 1 & 0.2 \\
\hline Douglas Terrace & 21,102 & 18,720 & 3.2 & 130 & 220 & 260 & 370 \\
\hline Below East Branch West River confluence & 18,663 & 15,334 & 4.2 & 190 & 320 & 380 & 540 \\
\hline Upstream of Whipple's Pond Dam & 14,762 & 9,970 & 7.3 & 380 & 640 & 770 & 1,110 \\
\hline Veazie Street & 9,678 & 5,837 & 7.8 & 430 & 740 & 880 & 1,270 \\
\hline Below Upper Canada Pond Brook confluence & 5,665 & 1,534 & 10.9 & 640 & 1,090 & 1,310 & 1,900 \\
\hline Below overflow diversion & 1,386 & 35 & 11.0 & 650 & 1,000 & 1,070 & 1,170 \\
\hline
\end{tabular}

'The drainage area is the downstream point ("To" station) where the flow was determined; the "From" station and "Description" is the upstream point where the flow is first specified.

Table 1-4. Annual exceedance probability flows specified in the hydraulic model for the East Branch West River, Lincoln Downs Brook, and Upper Canada Pond Brook, Rhode Island.

$\left[\mathrm{mi}^{2}\right.$, square mile; $\mathrm{ft}^{3} / \mathrm{s}$, cubic feet per second $]$

\begin{tabular}{|c|c|c|c|c|c|c|c|}
\hline \multirow[t]{2}{*}{ Description } & \multicolumn{2}{|c|}{ Cross section station } & \multirow{2}{*}{$\begin{array}{c}\text { Drainage } \\
\text { area }^{1} \\
\left(\mathrm{mi}^{2}\right)\end{array}$} & \multicolumn{4}{|c|}{$\begin{array}{c}\text { Discharge }\left(\mathrm{ft}^{3} / \mathrm{s}\right) \text { for specified percent annual } \\
\text { exceedance probability }\end{array}$} \\
\hline & From & To & & 10 & 2 & 1 & 0.2 \\
\hline Lincoln Downs Brook & 5,064 & 160 & 1.99 & 150 & 250 & 300 & 440 \\
\hline Upper Canada Pond Brook, upper reach & 6,491 & 1,522 & 1.18 & 90 & 160 & 190 & 280 \\
\hline
\end{tabular}

${ }^{1}$ The drainage area is the downstream point ("To" station) where the flow was determined; the "From" station and "Description" is the upstream point where the flow is first specified.

\section{Woonasquatucket River}

Flows specified for the Woonasquatucket River were determined from annual peak-flow records from the Centerdale, R.I. (01114500), streamgage for 1941-2010, weighted with the regional-regression equation values (Zarriello and others, 2012). Discharges at locations within \pm 50 percent of the drainage area of the streamgage (table 1-5) were adjusted from the gaged location using the simple drainage area ratio method (Zarriello and others, 2012). The discharges at the upstream end of the model (above Old Forge Road) were determined by the regional flood-flow regression equations (Zarriello and others, 2012). Below the confluence of the Woonasquatucket and Moshassuck Rivers, the flows at the selected AEPs are the sum of flows at the mouth of the Woonasquatucket and Moshassuck Rivers.

\section{Hydraulic Analyses}

Hydraulic analyses of selected reaches were done using HEC-RAS version 4.1.0 (Brunner, 2010a and b). The initial scope of the study was to update the existing FIS hydraulic models to HEC-RAS. As previously noted, it became apparent that the model conveyance was not always representative of current conditions. In addition, a simple conversion of the model could cause other problems, such 
Table 1-5. Annual exceedance probability flows specified in the hydraulic model for the Woonasquatucket River, Rhode Island. $\left[\mathrm{mi}^{2}\right.$, square miles; $\mathrm{ft}^{3} / \mathrm{s}$, cubic feet per second; USGS, U.S. Geological Survey]

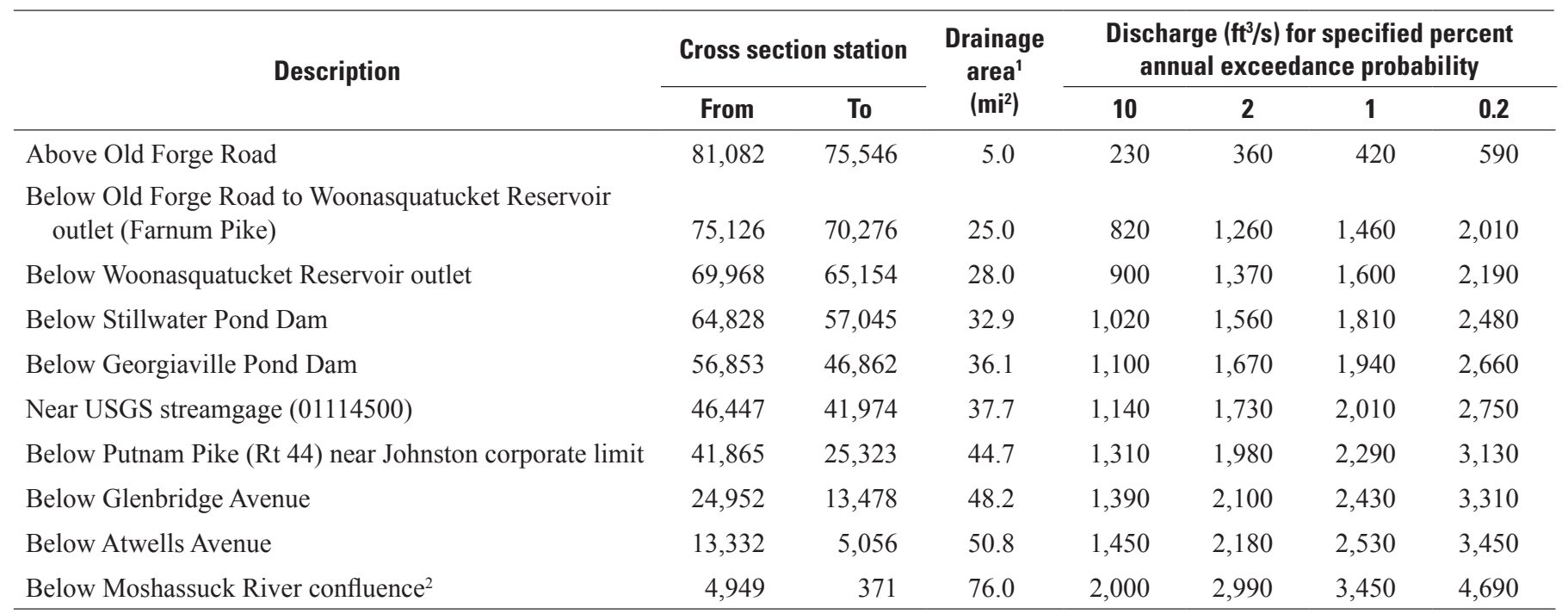

${ }^{1}$ The drainage area is the downstream point ("To" station) where the flow was determined; the "From" station and "Description" is the upstream point where the flow is first specified.

${ }^{2}$ Below the confluence the discharge was determined by the sum of the flows from each river for the respective exceedance probability flows.

as improper georeferencing riverine structures. Field survey data collected during this study, together with the use of recent available LiDAR data, improved the representativeness of the river hydraulic models and the simulated flood water-level simulations. Field survey data and LiDAR data were incorporated into the updated models using the HECGeoRAS (Ackerman, 2011), which allows the exchange of georeferenced information with the HEC-RAS model.

After the initial hydraulic model simulations were done, the error and warning messages generated by HEC-RAS and FEMA's CHECK-RAS application were reviewed. The results were assessed for validity, accuracy, and appropriate engineering practices. Some of the areas of concern included the critical water-surface calculations, WSE differences between adjacent cross-sections, and correct usage of ineffective-flow areas. After revisions were made to the model, the model was run again and the results were reviewed; the process was repeated until the remaining warnings were judged acceptable.

\section{Solution Check at Bridges and Culverts}

During high-flow conditions, pressure flow may occur at bridges and culverts when the water surface on the upstream side of the structure equals or exceeds the low chord of the bridge or the top of the culvert. The possibility of this type of condition was checked at all bridges and culverts where the WSE derived from the energy equation was found to be near the low chord of a bridge or the top of the culvert. Although the energy-equation method is applicable to the widest range of hydraulic problems (Brunner, 2010b) pressure-flow computations are needed when the water surface comes into contact with the low bridge chord or top of the culvert. In a number of cases, pressurized flow is controlled by the downstream WSE, and a coefficient for the applicable flow equation is specified.

During high-flow conditions, road overflow may occur, which results in weir flow if the structure is not submerged (sufficient drop in the water surface on the downstream side of the structure). Submergence is determined as a function of the ratio of the downstream flow depth to the upstream energy grade line, as measured from the minimum high chord of the bridge deck (Warner and others, 2010). The HEC-RAS uses a default maximum submergence ratio of 0.95 for weir-flow calculations. When the 0.95 ratio is exceeded HEC-RAS Applications Guide (Warner and others, 2010) states:

"When this ratio is exceeded for a bridge analysis, the program will switch from the weir-flow equation to the energy method to determine the upstream flow depth. For a culvert analysis, this ratio is not used because the program cannot perform a backwater analysis through a culvert flowing full. Therefore, a weir analysis will always be used when overflow occurs."

As a result, when road overflow occurs at a culvert and the weir-flow computation is determined to be invalid, other modeling techniques are used to account for an energy-based solution. For this condition, the roadbed does not act like a weir and a weir-flow coefficient for submergence is used. 


\section{Moshassuck River}

A HEC-RAS model was developed for a $10.1 \mathrm{mi}$ reach of the Moshassuck River from the confluence with the Woonasquatucket River to near its headwaters (fig. 1-1). The model also includes tributary reaches in the basin that are connected by junctions described later in this report. The model was developed from (1) cross-section and riverinestructure data surveyed in the field by the USGS, (2) the effective FIS, and (3) 2011 LiDAR data. Peak discharges estimated for 10-, 2-, 1-, and 0.2-percent AEP floods were used with cross-sectional and riverine structure information to compute the corresponding water-surface profiles.

\section{Model Limit and Baseline Stationing}

The Moshassuck River generally flows southeast then south in central Rhode Island. The model starts at its confluence with the Woonasquatucket River and ends at the outlet of Limerock Reservoir near the intersection of Route 146 and Interstate 295. Stationing for the model is in feet referenced from the mouth of the river (as determined by the where the stream centerline joins the centerline of the WoonasquatucketProvidence River) about $300 \mathrm{ft}$ downstream of Angell Street.

\section{Cross-Section and Structural Geometry Data}

The Moshassuck River model is divided into three river segments (fig. 1-1; table 1-6) - upper reach, lower reach, and a short reach below a diversion conduit from the West River. The upper reach is above junction J4 that demarks the West River confluence. The lower reach is between the West River confluence (J4) and the confluence of the diversion from the West River (J5). The reach, "ds Diversion" is below the confluence of where the diversion rejoins the main stem (J5) and the confluence with the Woonasquatucket River.

The reaches that define the Moshassuck River portion of the hydraulic model consist of 332 cross sections, 26 bridges, 13 culverts, and 6 dams. The USGS surveyed 30 riverine structures, 29 approaches; other cross sections were obtained from the effective FIS. Elevations from LiDAR data were used to supplement or extend the cross sections as needed. All survey and model data are referenced to North American Datum of 1983 (NAD 83) horizontal datum and North American Vertical Datum of 1988 (NAVD 88) vertical datum.

Eight interpolated cross sections were generated between the confluence of the West River and the junction where the West River overflow rejoins the main stem. These sections were interpolated in pairs between existing cross sections that were generally similar in shape. Sections at the upstream and downstream faces of structures were sometimes interpolated from the approach and exit cross sections, and the structure geometry. Upstream and downstream faces of structures are not included in table 1-6. Levees, ineffective flow areas, and obstructions were specified in channel cross sections as needed.

\section{Starting Water-Surface and Backwater Elevation}

The Moshassuck River is affected by backwater conditions from Providence River, which is tidal but the stage can be controlled by the Fox Point Hurricane Barrier that separates the Providence River from Narragansett Bay during storm surges. Large capacity pumps can move riverine water over the barrier when the tide gates are closed to maintain a water level generally below $8.67 \mathrm{ft}$ (NAVD 88); barrier operators try to keep the water-level below $8.87 \mathrm{ft}$ (NAVD 88) as this is the level when low lying streets in the area begin to flood (Paul Marinelli, U.S. Army Corps of Engineers, written commun., July 5, 2011). For purposes of this model, the starting WSE was specified at the maximum reported elevation of $9.29 \mathrm{ft}$ (NAVD 88) in the Providence River during the 2010 flood (Larry Davis, U.S. Army Corps of Engineers, written commun., July 5, 2011) .

\section{Manning's Roughness Coefficients}

Manning's roughness coefficients ( $n$ ) for the main channel and overbank areas of the Moshassuck River were transferred from the effective FIS model, which were constant throughout the model, with values of 0.040 specified for the main channel and 0.100 for the overbank. Initial comparison of simulated WSEs to the 2010 HWM elevations indicated an excessive roughness, and the model values were adjusted downward. Revised roughness coefficients range in value from 0.032 to 0.035 for the main channel with a median of 0.032 , and from 0.052 to 0.085 for the overbank areas with a median value of 0.075 .

\section{Flow Lengths}

Main channel and overbank flow lengths were computed through the use of HEC-GeoRAS. Flow paths were defined by the NHD (http://nhd.usgs.gov/) stream centerline and by the modeler for the overbanks. The median main channel length between cross sections was $99 \mathrm{ft}$ and ranged from 11 to $2,542 \mathrm{ft}$. Short and long channel lengths typically are caused by meanders in the river.

\section{Hydraulic Structures}

Water levels in the Moshassuck River can be affected by 26 bridges, 13 culverts, and 6 dams. Table 1-7 lists the type of structures and the solution type used at bridges to compute the flood profile for the 1-percent AEP flow. Road overflow at the 1 percent AEP flow is noted. The solution type at bridges was determined by the model on the basis of the simulated conditions at the structure, which can vary according to the AEP flow.

Table 1-6. Summary of cross sections in the hydraulic model for the Moshassuck River, Rhode Island.

[Available separately at http://pubs.usgs.gov/sir/2013/5191/ tables/sir2013-5191_Appendix1.xls] 


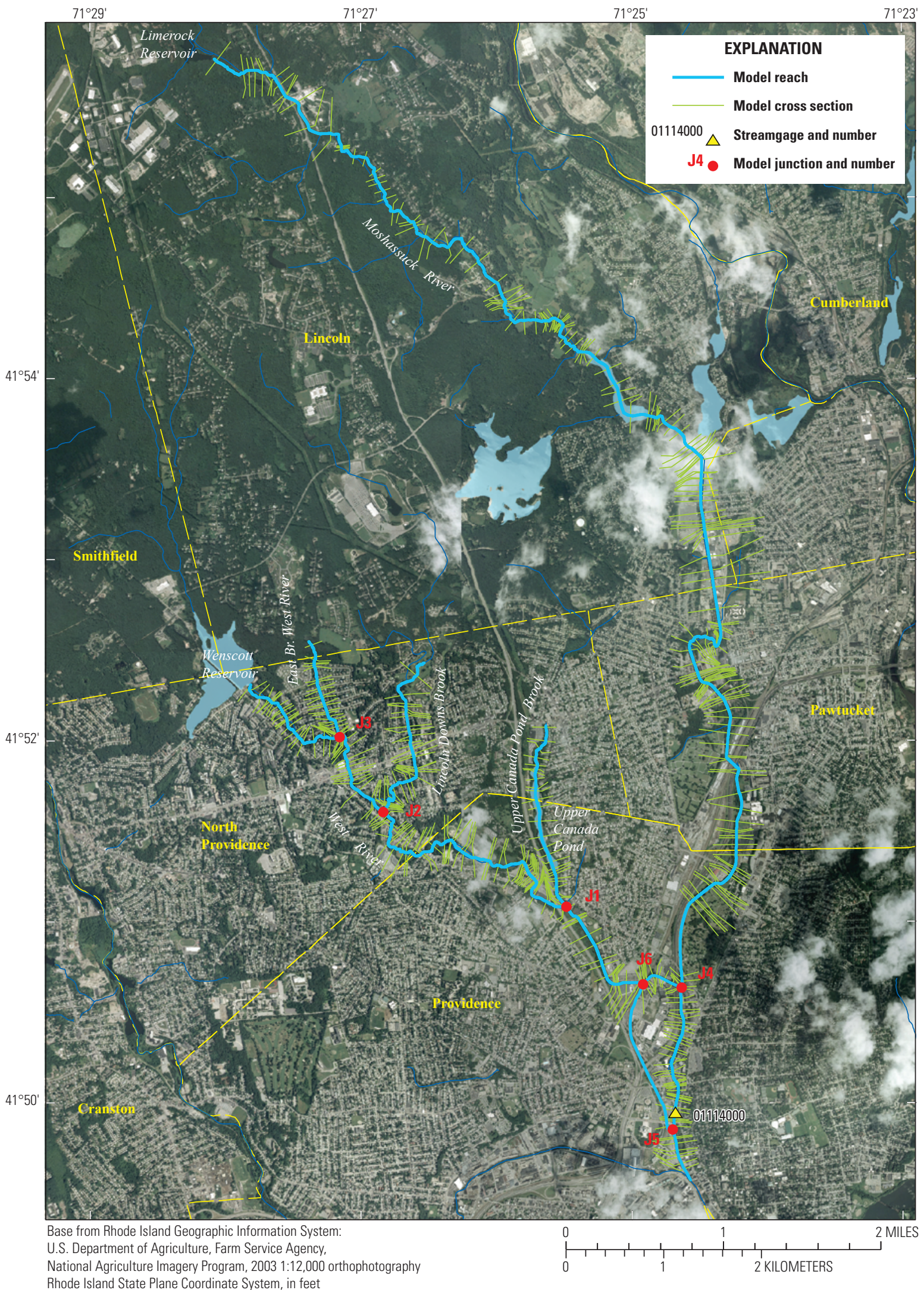

Figure 1-1. Reaches in the hydraulic model for Moshassuck River, West River, East Branch West River, Lincoln Downs Brook, and Upper Canada Pond Brook, Rhode Island. 


\section{West River}

The West River is part of the Moshassuck River HECRAS model and is identified by its name and the reaches "West Branch", "Upper Reach", "Middle Reach", "Lower Reach", and "ds Amtrak". The model portion of the West River runs from the confluence with the Moshassuck River for 4.3 mi upstream to the outlet of Wenscott Reservoir (fig. 1-1). The "West Branch" is the upstream most reach above the confluence of East Branch West River at junction J3. The "Upper Reach" is the segment between the East Branch West River and Lincoln Downs Brook between junctions J3 and J2. The "Middle Reach" is the segment between Lincoln Downs Brook and Upper Canada Pond Brook between junctions J2 and J1. The "Lower Reach" is the segment between Upper Canada Pond Brook and the railroad overflow diversion between junctions J1 and J6. The "ds Amtrak" is the segment below the overflow diversion to the confluence of the Moshassuck River between junctions J6 and J4.

A diversion channel about $0.3 \mathrm{mi}$ long identified as "Surface Flow" and the reach "Amtrak ROW" is a conduit for high-water overflow from the West River down a railroad right-of-way (between junctions J6 and J5). Prior to the installation of a diversion conduit in the lower part of the overflow channel in the early 1980s, the overflow channel drained into the Woonasquatucket River; the diversion conduit redirects the flow back into the Moshassuck River about 1,400 ft above the confluence with the Woonasquatucket River. For convenience, and because the overflow is from the West River, the characteristics of the overflow channel are included in this section.

The model was developed from cross-section and riverine structure data surveyed in the field by the USGS, from the effective FIS, and from 2011 LiDAR data. Peak discharges estimated for 10-, 2-, 1-, and 0.2-percent AEP floods were used with cross-sectional and riverine-structure information to compute the corresponding water-surface profiles.

\section{Model Limit and Baseline Stationing}

The West River generally flows southeast in central Rhode Island. The model starts at its confluence with the Moshassuck River and ends at the outlet of Wenscott Reservoir. Stationing for the model is in feet referenced from the mouth of the river. The overflow diversion stationing is referenced in feet from the mouth of the Moshassuck River.

\section{Cross-Section and Structural-Geometry Data}

The West River portion of the model consists of 165 cross sections, 15 bridges, 6 culverts, and 3 dams (fig. 1-1; table 1-8). The USGS surveyed 19 riverine structures, 19 approaches, and 17 exits for the model (note one structure was a dam under a bridge); other cross sections were obtained from the effective FIS and from LiDAR data. The overflow diversion consists of 16 cross sections and no structures; these sections were determined from LiDAR data. All survey and model data are referenced to NAD 83 horizontal datum and NAVD 88 vertical datum.

Twelve interpolated cross section were generated between the confluence of the Lincoln Downs and Upper Canada Pond Brooks. Sections at the upstream and downstream faces of structures were interpolated from the approach and exit cross sections, and the structure geometry. Upstream and downstream faces of structures are not included in table 1-8. Levees, ineffective flow areas, and obstructions were specified in channel cross sections as needed.

\section{Starting Water-Surface and Backwater Elevation}

The West River is affected by backwater conditions from the Moshassuck River. The starting elevation is determined internally by the simulated WSE at junction J4 in the Moshassuck River for flood flows of similar exceedance probabilities. Backwater from the Moshassuck River largely determines the overflow through the diversion channel (Amtrak ROW).

\section{Manning's Roughness Coefficients}

Manning's roughness coefficients (n) for the main channel and overbank areas were transferred from the effective FIS model, which were constant throughout the model, with values of 0.040 specified for the main channel and 0.100 for the overbank. Initial comparisons of the simulated WSEs to the 2010 HWM elevations in the Moshassuck River indicated an excessive roughness and the "n" values were adjusted downward to 0.034 for the main channel and 0.094 for the overbank areas.

\section{Flow Lengths}

Main-channel and overbank-flow lengths were computed through the use of HEC-GeoRAS. Flow paths were defined by the NHD stream centerline and by the modeler for the overbanks. The median main channel length between cross sections was $74 \mathrm{ft}$ and ranged from 1 to $689 \mathrm{ft}$. Short and long channel lengths typically are caused by meanders in the river.

\section{Hydraulic Structures}

Water levels in the West River can be affected by 15 bridges, 6 culverts, and 3 dams. For this study, hydraulic structure computations were reviewed for the appropriate modeling solutions. Table 1-9 lists the type of structures and the solution type at bridges used to compute the flood profile for the 1-percent AEP flow. Road overflow at the 1-percent AEP flow is noted. The solution type at bridges was determined by the model on the basis of the simulated conditions at the structure, which can vary according to the AEP flow. 
Table 1-7. Summary of structures in the hydraulic model for the Moshassuck River, Rhode Island.

[River station rounded to the nearest foot; AEP, annual exceedance probability; USGS, U.S. Geological Survey; Inl Struct, in line structure; --, not applicable; Press/weir, pressure and weir flow]

\begin{tabular}{|c|c|c|c|c|}
\hline \multirow{2}{*}{$\begin{array}{l}\text { River station } \\
\text { (feet) }\end{array}$} & \multirow{2}{*}{ Description } & \multirow{2}{*}{ Structure type } & \multicolumn{2}{|c|}{ 1-percent AEP flow } \\
\hline & & & Road overflow & Solution type \\
\hline 889 & Park Row & Bridge & No & Pressure \\
\hline 1,982 & Smith Street & Bridge & No & Energy \\
\hline 2,621 & Charles Street (Route 246) & Bridge & No & Pressure \\
\hline 2,899 & Weir at USGS streamgage $(01114000)$ & Inl Struct & -- & -- \\
\hline 2,930 & Footbridge above USGS streamgage & Bridge & Yes & Press/weir \\
\hline 3,258 & Footbridge below Stevens Street & Bridge & Yes & Press/weir \\
\hline 3,403 & Footbridge below Stevens Street & Bridge & Yes & Press/weir \\
\hline 3,698 & Stevens Street & Bridge & Yes & Press/weir \\
\hline 3,903 & Randall Street & Bridge & Yes & Press/weir \\
\hline 5,536 & Industrial Drive & Bridge & No & Energy \\
\hline 6,503 & Interstate 95 north exit ramp & Bridge & No & Energy \\
\hline 6,819 & Interstate 95 north on ramp & Culvert & No & -- \\
\hline 8,355 & Unnamed long culvert & Culvert & $\mathrm{No}^{1}$ & -- \\
\hline 9,811 & Cemetery access & Bridge & Yes & Energy $^{2}$ \\
\hline 10,648 & Cemetery Street (Frost Street) & Culvert & $\mathrm{No}^{1}$ & -- \\
\hline 11,458 & Smithfield Avenue & Culvert & Yes & -- \\
\hline 12,706 & Grenville Street & Culvert & Yes & -- \\
\hline 15,200 & Interstate 95 and railroad & Bridge & No & Energy \\
\hline 17,574 & Grotto Avenue & Bridge & Yes & Press/weir \\
\hline 18,347 & Abandoned railroad & Bridge & No & Energy \\
\hline 18,416 & Unnamed & Culvert & Yes & -- \\
\hline 18,742 & Mineral Spring Avenue & Bridge & Yes & Press/weir \\
\hline 21,121 & Private drive & Bridge & Yes & Press/weir \\
\hline 21,921 & Weeden Street & Bridge & No & Energy \\
\hline 25,174 & Higginson Avenue & Bridge & Yes & Press/weir \\
\hline 26,377 & Abandoned railroad & Bridge & Yes & Pressure \\
\hline 28,013 & Walker Street & Bridge & No & Energy \\
\hline 29,802 & Smithfield Road & Bridge & Yes & Energy \\
\hline 30,070 & Barney Pond Dam & Inl Struct & -- & -- \\
\hline 33,602 & Table Rock Road & Bridge & No & Energy \\
\hline 35,086 & Great Road 2 & Culvert & No & -- \\
\hline 35,218 & Moffet Dam & Inl Struct & -- & -- \\
\hline 35,698 & Great Road 1 & Culvert & No & -- \\
\hline 35,877 & Old mill dam & Inl Struct & -- & -- \\
\hline 36,292 & Private drive 2 below Breakneck Hill Road & Bridge & Yes & Energy \\
\hline 37,405 & Private drive 1 below Breakneck Hill Road & Bridge & No & Energy \\
\hline 37,718 & Breakneck Hill Road & Culvert & No & -- \\
\hline 37,872 & Dam above Breakneck Hill Road (Butterfly Pond) & Inl Struct & -- & -- \\
\hline 42,872 & Private road at Fairlawn Golf Course & Culvert & Yes & -- \\
\hline 45,030 & Private road and pond weir & Bridge & No & Energy \\
\hline 45,072 & Earth dam & Inl Struct & -- & -- \\
\hline 45,318 & Private earth dam with culverts & Culvert & Yes & -- \\
\hline 47,117 & Sherman Avenue & Bridge & Yes & Energy \\
\hline 49,873 & Route 146 & Culvert & No & -- \\
\hline 51,340 & Old Louisquisset Road & Culvert & Yes & -- \\
\hline
\end{tabular}

${ }^{1}$ Road overflow at the 0.2-percent AEP flow.

${ }^{2}$ Converted to energy equation because of downstream submergence. 
Table 1-8. Summary of cross sections in the hydraulic model for the West River, Rhode Island.

[Available separately at http://pubs.usgs.gov/sir/2013/5191/ tables/sir2013-5191_Appendix1.xls]

\section{East Branch West River}

The East Branch West River is part of the Moshassuck River HEC-RAS model and is identified by "East Branch" and reach "West River". The model portion of the East Branch West River runs from the confluence with the West River to 0.6 mi upstream (fig. 1-1). The model was developed from cross-section and riverine-structure data surveyed in the field by the USGS, from the effective FIS, and from 2011 LiDAR data. Peak discharges estimated for 10-, 2-, 1-, and 0.2-percent AEP floods were used with cross-sectional and riverine structure information to compute the corresponding watersurface profiles.

\section{Model Limit and Baseline Stationing}

The East Branch West River generally flows south in central Rhode Island. The model starts at its confluence with the West River and ends about 3.5 mi upstream. Stationing for the model is in feet referenced from the confluence with the West River (junction J3).

\section{Cross-Section and Structural-Geometry Data}

The East Branch West River portion of the model is defined by a single reach (fig. 1-1; table 1-10) consisting of 41 cross sections including 1 bridge and 6 culverts. The USGS surveyed four riverine structures, four approaches, and four exits for the model; other cross sections were obtained from the effective FIS. Elevations from LiDAR data were used to supplement or extend the cross sections as needed. All survey and model data are referenced to NAD 83 horizontal datum and NAVD 88 vertical datum.

Table 1-9. Summary of structures in the hydraulic model for the West River, Rhode Island.

[River station rounded to the nearest foot; AEP, annual exceedance probability; --, not applicable; Press/weir, pressure and weir flow; Inl Struct, in line structure]

\begin{tabular}{|c|c|c|c|c|}
\hline \multirow{2}{*}{$\begin{array}{c}\text { River station } \\
\text { (feet) }\end{array}$} & \multirow{2}{*}{ Description } & \multirow{2}{*}{ Structure type } & \multicolumn{2}{|c|}{ 1-percent AEP flow } \\
\hline & & & Road overflow & Solution type \\
\hline 141 & Interstate 95 & Culvert & No & -- \\
\hline 875 & West River Street & Bridge & Yes & Press/weir \\
\hline 940 & Abandoned railroad & Bridge & $\mathrm{No}^{1}$ & Pressure \\
\hline 1,338 & Abandoned railroad & Bridge & Yes & Press/weir \\
\hline 1,622 & Railroad & Bridge & No & Energy \\
\hline 1,695 & Abandoned railroad & Bridge & No & Energy \\
\hline 2,485 & Charles Street & Bridge & No & Pressure \\
\hline 5,134 & Hawkins Street & Bridge & No & Energy \\
\hline 5,974 & Route 146 & Culvert & Yes & -- \\
\hline 7,296 & Conduit beneath parking lot & Bridge & Yes & Press/weir \\
\hline 7,452 & Branch Avenue & Bridge & Yes & Press/weir \\
\hline 8,311 & U-Stor-It access & Bridge & $\mathrm{No}^{1}$ & Energy \\
\hline 9,651 & Veazie Street & Bridge & No & Momentum \\
\hline 10,591 & Wild Street & Bridge & Yes & Press/weir \\
\hline 11,136 & Dam near Burton (Whipple Pond) & Inl-Struct & -- & -- \\
\hline 12,514 & Douglas Avenue (downstream) & Bridge & No & Energy \\
\hline 13,995 & Private bridge & Bridge & No & Energy \\
\hline 14,510 & Douglas Avenue (upstream) & Bridge & Yes & Press/weir \\
\hline 17,135 & Mineral Spring Avenue & Culvert & No & -- \\
\hline 18,744 & West River Parkway & Culvert & No & -- \\
\hline 20,331 & Brookfarm Road & Culvert & No & -- \\
\hline 21,076 & Douglas Terrace & Culvert & Yes & -- \\
\hline 21,100 & Weir & Inl-Struct & -- & -- \\
\hline 22,005 & Unnamed (weir with a culvert) & Inl-Struct & -- & -- \\
\hline
\end{tabular}

${ }^{1}$ Road overflow at the 0.2 -percent AEP flow. 
Table 1-10. Summary of cross sections in the hydraulic model for the East Branch West River, Rhode Island.

[Available separately at http://pubs.usgs.gov/sir/2013/5191/ tables/sir2013-5191_Appendix1.xls]

Eight interpolated cross sections were generated in the reach. These sections were interpolated in pairs between existing cross sections that were generally similar. Sections at the upstream and downstream faces of structures were interpolated from the approach and exit cross sections, and the structure geometry. Upstream and downstream faces of structures are not included in table 1-10. Ineffective-flow areas and obstructions were specified in channel cross sections as needed.

\section{Starting Water-Surface and Backwater Elevation}

The East Branch West River is affected by backwater conditions from the West River. The starting elevation is determined internally by the model-simulated WSEs at the confluence in the West River (junction J3) for flood flows at similar exceedance probabilities.

\section{Manning's Roughness Coefficients}

Manning's roughness coefficients (n) for the main channel and overbank areas were transferred from the effective FIS model, which were generally constant throughout the model, with values of 0.040 specified for the main channel and 0.100 for the overbank. Initial comparison of simulated WSEs to the 2010 HWM elevation in the Moshassuck River that used similar "n" values indicated an excessive roughness and the " $n$ " values were adjusted downward to 0.032 for the main channel and to 0.092 for the overbank areas.

\section{Flow Lengths}

Main-channel and overbank-flow lengths were computed through the use of HEC-GeoRAS. Flow paths were defined by the NHD stream centerline and by the modeler for the overbanks. The median main channel length between cross sections was $69 \mathrm{ft}$ and ranged from 23 to $552 \mathrm{ft}$. Short and long channel lengths typically are caused by meanders in the river.

\section{Hydraulic Structures}

Water levels in the East Branch West River can be affected by one bridge and six culverts. For this study, hydraulic-structure computations were reviewed for the appropriate modeling solutions. Table 1-11 lists the type of structures and the solution type used at the bridge to compute the flood profile for the 1-percent AEP flow. Road overflow at the 1-percent AEP flow is noted. The solution type at the bridge was determined by the model on the basis of the simulated conditions at the structure, which can vary according to the AEP flow.
Table 1-11. Summary of structures in the hydraulic model for the East Branch West River, Rhode Island.

[River station rounded to the nearest foot; AEP, annual exceedance probability; --, not applicable]

\begin{tabular}{|c|c|c|c|c|}
\hline \multirow{2}{*}{$\begin{array}{c}\text { River } \\
\text { station } \\
\text { (feet) }\end{array}$} & \multirow[b]{2}{*}{ Description } & \multirow{2}{*}{$\begin{array}{c}\text { Structure } \\
\text { type }\end{array}$} & \multicolumn{2}{|c|}{ 1-percent AEP flow } \\
\hline & & & $\begin{array}{c}\text { Road } \\
\text { overflow }\end{array}$ & $\begin{array}{c}\text { Solution } \\
\text { type }\end{array}$ \\
\hline 57 & Brookdale Road & Culvert & $\mathrm{No}^{1}$ & -- \\
\hline 673 & Brookfarm Road & Culvert & No & -- \\
\hline 988 & Pinewood Drive & Culvert & $\mathrm{No}^{1}$ & -- \\
\hline 1,260 & Conifer Drive & Culvert & Yes & -- \\
\hline 1,530 & Sorrell Road & Culvert & Yes & -- \\
\hline 1,804 & Carriage Way & Culvert & $\mathrm{No}^{1}$ & -- \\
\hline 2,656 & Forest View Drive & Bridge & No & Energy \\
\hline
\end{tabular}

${ }^{1}$ Road overflow at the 0.2 -percent AEP flow.

\section{Lincoln Downs Brook}

Lincoln Downs Brook is part of the Moshassuck River HEC-RAS model and identified by "Lincoln Downs" and segment "Lower Reach". The model portion of the Lincoln Downs Brook runs from the confluence with the West River to about 1.0 mi upstream (fig. 1-1). The model was developed from cross-section and riverine-structure data surveyed in the field by the USGS, from the effective FIS, and from 2011 LiDAR data. Peak discharges estimated for 10-, 2-, 1-, and 0.2 -percent AEP floods were used with cross-sectional and riverine-structure information to compute the corresponding water-surface profiles.

\section{Model Limit and Baseline Stationing}

The Lincoln Downs Brook generally flows south in central Rhode Island. The model starts at its confluence with the West River and ends about 2.9 mi upstream. Stationing for the model is in feet referenced from the confluence with the West River (junction J2).

\section{Cross-Section and Structural-Geometry Data}

The Lincoln Downs Brook portion of the model is defined by a single reach (fig. 1-1; table 1-12) consisting of 46 cross sections, 1 bridge, and 7 culverts. The USGS surveyed eight riverine structures, seven approaches, and two exits for the model; most other cross sections were obtained from the effective FIS. Elevations from LiDAR data were used to supplement or extend the cross sections as needed. All survey and model data are referenced to NAD 83 horizontal datum and NAVD 88 vertical datum. 
Table 1-12. Summary of cross sections in the hydraulic model for Lincoln Downs Brook, Rhode Island.

[Available separately at http://pubs.usgs.gov/sir/2013/5191/ tables/sir2013-5191_Appendix1.xls]

Seven interpolated cross sections were generated for the reach. These sections were interpolated between existing cross sections that were generally similar. Sections at the upstream and downstream faces of structures were interpolated from the approach and exit cross sections, and the structure geometry. Upstream and downstream faces of structures are not included in table 1-12. Levees, ineffective-flow areas, and obstructions were specified in channel cross sections as needed.

\section{Starting Water-Surface and Backwater Elevation}

The Lincoln Downs Brook is affected by backwater conditions from the West River. The starting elevation is determined internally by the model simulated WSEs at the confluence in the West River (junction J2) for flood flows at similar exceedance probabilities.

\section{Manning's Roughness Coefficients}

Manning's roughness coefficients (n) for the main channel and overbank areas were transferred from the effective FIS model, which were constant throughout the model, with values of 0.040 specified for the main channel and 0.100 for the overbank. Initial comparison of simulated WSEs to the 2010 HWM elevation in the Moshassuck River that used similar " $n$ " values indicated an excessive roughness, and the " $n$ " values were adjusted downward to 0.034 for the main channel and to 0.094 for the overbank areas.

\section{Flow Lengths}

Main-channel and overbank flow lengths were computed through the use of HEC-GeoRAS. Flow paths were defined by the NHD stream centerline and by the modeler for the overbanks. The median main channel length between cross sections was $79 \mathrm{ft}$ and ranged from 18 to $537 \mathrm{ft}$. Short and long channel lengths typically are caused by meanders in the river.

\section{Hydraulic Structures}

Water levels in the Lincoln Downs Brook can be affected by one bridge and seven culverts. For this study, hydraulic structure computations were reviewed for the appropriate modeling solutions. Table 1-13 lists the type of structures and the solution type used at bridges to compute the flood profile for the 1-percent AEP flow. Road overflow at the 1-percent AEP flow is noted. The solution type at bridges was determined by the model on the basis of the simulated conditions at the structure, which can vary according to the AEP flow.

\section{Upper Canada Pond Brook}

Upper Canada Pond Brook is part of the Moshassuck River model and is identified by "Upper Canada Pond" and segment "Lower Reach". The model portion of Upper Canada Pond Brook runs from the confluence with the West River to 1.2 mi upstream (fig. 1-1); a $0.6 \mathrm{mi}$ section of the reach flows through Upper Canada Pond. The brook parallels Route 146 just east of the north bound lane. The model was developed from cross section and riverine structure data surveyed in the field by the USGS, from the effective FIS, and from 2011 LiDAR data. Peak discharges estimated for 10-, 2-, 1-, and

Table 1-13. Summary of structures in the hydraulic model for Lincoln Downs Brook, Rhode Island.

[River station rounded to the nearest foot; AEP, annual exceedance probability; --, not applicable; Press/weir, pressure and weir flow]

\begin{tabular}{clccc}
\hline \multirow{2}{*}{$\begin{array}{c}\text { River station } \\
\text { (feet) }\end{array}$} & \multicolumn{1}{c}{ Description } & Structure type & \multicolumn{2}{c}{ 1-percent AEP flow } \\
\cline { 4 - 5 } & & Road overflow & Solution type \\
\hline 240 & Wentworth Street & Culvert & Yes & -- \\
1,411 & Lexington Avenue & Culvert & Yes & -- \\
1,911 & Private drive near Maynard Street & Culvert & Yes & -- \\
2,451 & Mineral Spring Avenue & Culvert & Yes & -- \\
3,162 & Benjamin Drive & Culvert & Yes & -- \\
3,728 & Angell Road & Culvert & Yes & -- \\
4,511 & Golf cart path & Bridge & Yes & Press/weir \\
4,682 & Dam and golf cart path & Culvert & Yes & -- \\
\hline
\end{tabular}


0.2-percent AEP floods were used with cross-sectional and riverine-structure information to compute the corresponding water-surface profiles.

\section{Model Limit and Baseline Stationing}

The Upper Canada Pond Brook generally flows south in central Rhode Island. The model starts at its confluence with the West River and ends about 1.1 mi upstream. Stationing for the model is in feet referenced from the confluence with West River (junction J1).

\section{Cross-Section and Structural-Geometry Data}

The Upper Canada Pond Brook portion of the model is defined by a single reach (fig. 1-1; table 1-14) consisting of 31 cross sections, 1 bridge, 2 culverts, and 2 dams. The USGS surveyed three riverine structures, three approaches, and three exits for the model; other cross sections were obtained from the effective FIS model. Elevations from LiDAR data were used to supplement or extend the surveyed cross sections as needed. All survey and model data are referenced to NAD 83 horizontal datum and NAVD 88 vertical datum.

No synthetic generated cross sections were used in this model. However, sections at the upstream and downstream faces of structures were interpolated from the approach and exit cross sections, and the structure geometry. Upstream and downstream faces of structures are not included in table 1-14. Ineffective-flow areas and obstructions were specified in channel cross sections as needed.

Table 1-14. Summary of cross sections in the hydraulic model for Upper Canada Pond Brook, Rhode Island.

[Available separately at http://pubs.usgs.gov/sir/2013/5191/ tables/sir2013-5191_Appendix1.xls]

\section{Starting Water-Surface and Backwater Elevation}

The Upper Canada Pond Brook is affected by backwater conditions from the West River. The starting elevation is determined internally by the model simulated WSEs at the confluence in the West River (junction J1) for flood flows at similar exceedance probabilities.

\section{Manning's Roughness Coefficients}

Manning's roughness coefficients (n) for the main channel and overbank areas were transferred from the effective FIS model, which were constant throughout the model with values of 0.040 specified for the main channel and 0.100 for the overbank. Initial comparisons of simulated WSEs to the 2010 HWM elevations in the Moshassuck River that used similar "n" values indicated an excessive roughness, and the "n" values were adjusted downward to 0.034 for the main channel and to 0.094 for the overbank areas.

\section{Flow Lengths}

Main-channel and overbank-flow lengths were computed through the use of HEC-GeoRAS. Flow paths were defined by the NHD stream centerline and by the modeler for the overbanks. The median main channel length between cross sections was $233 \mathrm{ft}$ and ranged from 13 to $530 \mathrm{ft}$. Short and long channel lengths typically are caused by meanders in the river.

\section{Hydraulic Structures}

Water levels in the Upper Canada Pond Brook can be affected by one bridge, two culverts, and two dams. Table 1-15 lists the type of structures and the solution type used at the bridge to compute the flood profile for the 1-percent AEP flow. Road overflow at the 1-percent AEP flow is noted. The solution type at the bridge was determined by the model on the basis of the simulated conditions at the structure, which can vary according to the AEP flow.

Table 1-15. Summary of structures in the hydraulic model for Upper Canada Pond Brook, Rhode Island.

[River station rounded to the nearest foot; AEP, annual exceedance probability; Inl-Struct, in line structure; --, not applicable]

\begin{tabular}{cllcc}
\hline \multirow{2}{*}{$\begin{array}{c}\text { River station } \\
\text { (feet) }\end{array}$} & \multicolumn{1}{c}{ Description } & Structure type & \multicolumn{2}{c}{ 1-percent AEP flow } \\
\cline { 4 - 5 } & & Road overflow & Solution type \\
\hline 445 & Route 146 north exit ramp & Culvert & Yes & -- \\
655 & Branch Avenue & Culvert & Yes & -- \\
849 & Unnamed drop structure & Inl-Struct & -- & -- \\
1,327 & Footbridge downstream of dam & Bridge & No & Energy \\
1,414 & Upper Canada Pond dam & Inl-Struct & -- & -- \\
\hline
\end{tabular}


$71^{\circ} 32$

$71^{\circ} 28^{\prime}$

$71^{\circ} 24^{\prime}$

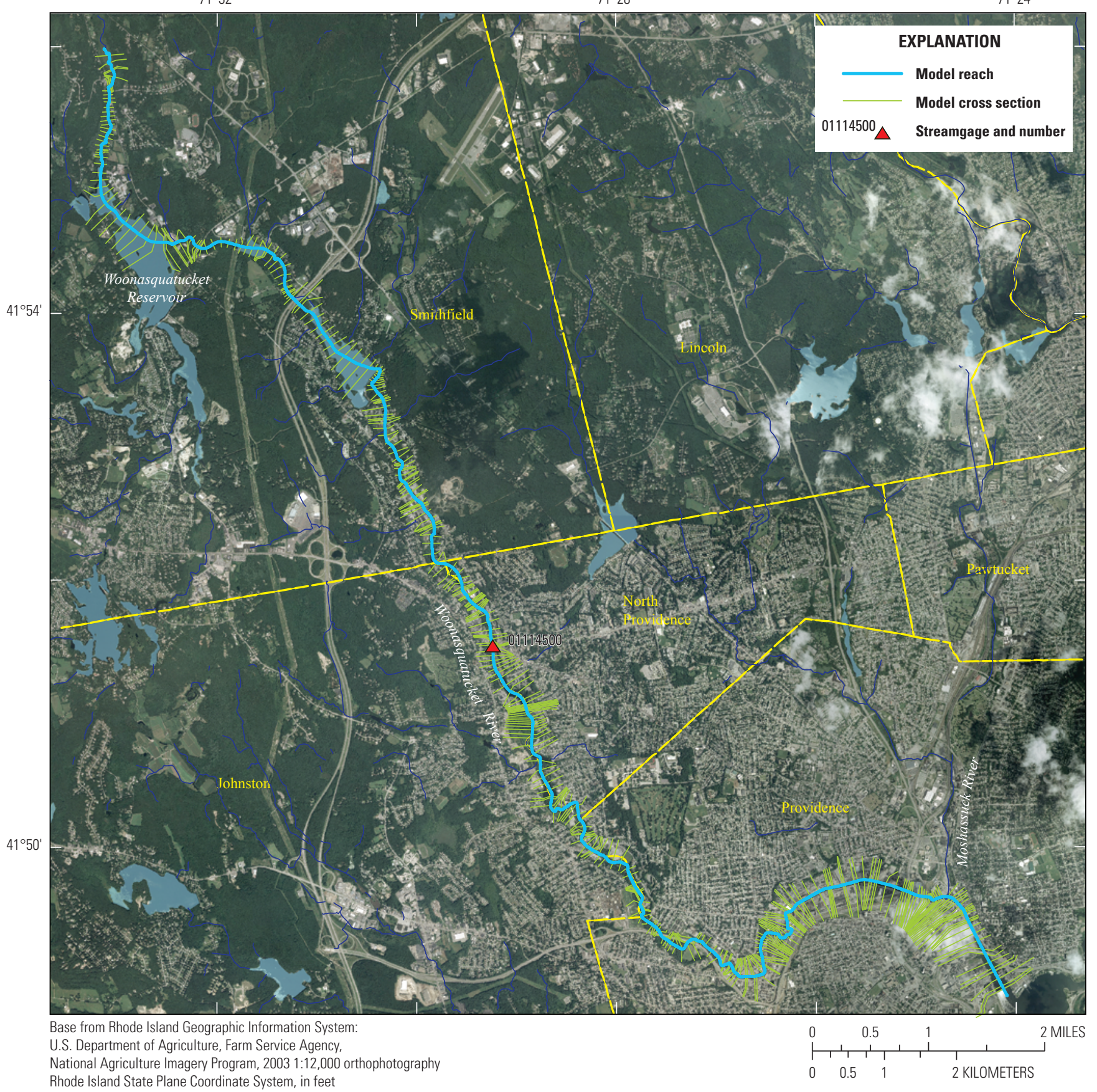

Figure 1-2. The hydraulic model for the Woonasquatucket River, Rhode Island. 


\section{Woonasquatucket River}

A HEC-RAS model was developed for $15.4 \mathrm{mi}$ of the Woonasquatucket River from Fox Point Hurricane Barrier (FPHB) to about $1 \mathrm{mi}$ above the Woonasquatucket Reservoir (fig. 1-2). The Woonasquatucket River model includes, for purposes of this study, the Providence River, which is the 0.9 mi reach from the confluence with the Moshassuck River to the FPHB. The model does not include any tributary reaches and is defined by a single reach segment. The model was developed from cross-section and riverine-structure data surveyed in the field by USGS, from the effective FIS, and from 2011 LiDAR data. Peak discharges estimated for 10-, 2-, 1-, and 0.2-percent AEP floods were used with crosssectional and riverine-structure information to compute the corresponding water-surface profiles.

\section{Model Limit and Baseline Stationing}

The Woonasquatucket River generally flows southeast in central Rhode Island. The model starts about $370 \mathrm{ft}$ downstream of FPHB and ends about 1 mi upstream of Woonasquatucket Reservoir. Stationing for the model is in feet referenced from the start of the river centerline at its mouth in Narragansett Bay.

\section{Cross-Section and Structural-Geometry Data}

The Woonasquatucket River model consists of 367 cross sections, 60 bridges, 4 culverts, and 16 dams (fig. 1-2; table 1-16). Three of the dams had been breached or removed since the effective FIS model was developed. The USGS surveyed 61 riverine structures, 57 approaches, and 59 exits for the model; other cross sections were obtained from the effective FIS. Elevations from LiDAR data were used to supplement or extend the cross sections as needed. The field surveys conducted during this study included all bridges and inline structures below Georgiaville Pond Dam (station 57,133) with the exception of three inline structures that are no longer present-Centerdale Dam (station 44,175), Dyersville Pond Dam (station 26,330), and Paragon Dam (station 17,351). All surveys were referenced to the NAD 83 horizontal datum and NAVD 88 vertical datum. The elevations for the hydraulic structures above the Georgiaville Pond Dam ( 6 bridges, 2 culverts, and 2 dams) were determined from the effective FIS and supplemented with the LiDAR data. Two old mill-factory buildings, which once used water power, cross the river. The exterior of the structures were surveyed by the USGS, but for safety reasons, no attempt was made to survey the interior of the structure. Most cross sections outside of the hydraulic structures were obtained from the effective FIS model and supplemented with the LiDAR data.
Table 1-16. Summary of cross sections in the hydraulic model for the Woonasquatucket River, Rhode Island.

\section{[Available separately at http://pubs.usgs.gov/sir/2013/5191/} tables/sir2013-5191_Appendix1.xls]

No synthetic cross sections were generated for the model. However, sections at the upstream and downstream faces of structures were interpolated from the approach and exit cross sections, and the structure geometry. Upstream and downstream faces of structures are not included in table 1-16. Levees, ineffective-flow areas, and obstructions were specified in channel cross sections as needed.

\section{Starting Water-Surface and Backwater Elevation}

The Woonasquatucket River is tidal but the stage can be controlled by the FPHB, which separates the Providence River from Narragansett Bay during storm surges. Under normal conditions the Providence River flows through three large gates into Narragansett Bay about 0.87 mi below the confluence. Five large capacity pumps (combined capacity of 7,000 ft3 3 s) can move riverine flow over the barrier when the tide gates are closed to maintain a water level generally below $8.67 \mathrm{ft}$ (NAVD 88). Operators try to keep the water level on the river side of the barrier to no greater than $8.87 \mathrm{ft}$ (NAVD 88), which is the level when low lying streets in the area begin to flood (Paul Marinelli, U.S. Army Corps of Engineers, written commun., July 5, 2011). For purposes of this model, the starting WSE was specified at the maximum reported elevation of $9.29 \mathrm{ft}$ (NAVD 88) in the Providence River during the 2010 flood (Larry Davis, U.S. Army Corps of Engineers, written commun., July 5, 2011).

The FPHB was built in the 1960s in response to the floods of 1938 and 1954 to prevent damage from hurricane storm surges. The FPHB is operated according to the coordination-guide document prepared by the Providence Emergency Management Agency (written commun., 2011), which is a revision to the FPHB, Providence, R.I., Operation and Maintenance Manual (Department of the Army, New England Division, Corps of Engineers, Waltham, Mass., written commun., September 1966). The FPHB has been principally operated and maintained by the USACE since 2010. The barrier was accredited by FEMA in August 2009 (Providence Emergency Management Agency, written commun., 2011), to provide protection from floods that have a 1-percent chance of being equaled or exceeded in any given year (assumed to refer to the tidal-surge protection capacity).

\section{Manning's Roughness Coefficients}

Manning's roughness coefficients (n) for the main channel and overbank areas of the Woonasquatucket River were determined by experienced personnel from field observation and aerial photographs. Estimates of Manning's roughness coefficients range from 0.025 to 0.042 for the main channel with a median of 0.037 , and from 0.028 to 0.085 for the overbank areas with a median of 0.075 . 


\section{Flow Lengths}

Main-channel and overbank-flow lengths were computed through the use of HEC-GeoRAS. Flow paths were defined by the NHD stream centerline and by the modeler for the overbanks. The median main-channel length between cross sections was $210 \mathrm{ft}$ and ranged from 23 to $495 \mathrm{ft}$. Short and long channel lengths typically are caused by meanders in the river.

\section{Hydraulic Structures}

Water levels in the Woonasquatucket River can be affected by 60 bridges, 4 culverts, and 16 dams. Hydraulic structure computations were reviewed for the appropriate modeling solutions. Table 1-17 lists the type of structures and the solution type used at bridges to compute the flood profile for the 1-percent AEP flow. Road overflow at the 1-percent AEP flow is noted. The solution type at bridges was determined by the model on the basis of the simulated conditions at the structure, which can vary according to the AEP flow.

Most all solutions are determined by the energy equation, but pressure flow was used at station 70,342 (Old Forge Road bridge) at high flows. In most cases, road overflow was not indicated at bridges at the 1-percent AEP, but road overflow was indicated at some bridges at the highest flow (0.2-percent AEP). Where road overflow did occur at a culvert (station 62,832; Capron Road), a submergence check was made for pressure and weir flow.

\section{Field Survey Quality Control}

At most structures that affect river conveyance such as bridges, culverts, and dams, the USGS conducted field surveys following FEMA guidelines and standards for data acquisition for flood mapping (FEMA, 2011). The USGS conducted both global positioning system (GPS) and conventional surveys for this study. The GPS surveys were conducted to establish control points at each section using Trimble R8 receivers, which support the L1, L2, and GLONASS L2C and L5 signals. Conventional surveys were conducted to obtain stream and hydraulic-structure geometry using the control points for vertical and horizontal reference. The horizontal position is in NAD 83 using Rhode Island State Plane coordinates and vertical elevation is in NAVD 88 . Thirdorder accuracy (horizontal and vertical) was maintained for all conventional survey data collected. Control for the USGS survey was established using National Geodetic Survey (NGS) monuments (benchmarks) with known horizontal or vertical coordinates, or both (table 1-18).

Continuous real-time differential corrections to the field GPS horizontal and vertical positions were made using a proprietary fixed-base station GPS network operated by KeyNetGPS, Inc. The network and associated software determines corrections for satellite signals received by the field GPS receiver for ionosphere and other atmospheric disturbances recorded at three or more of the closest fixedbase stations relative to the position of the field GPS receiver. The fixed-base station receivers continuously stream data to a central server, which calculates corrections in real time at the location of the field GPS receiver. The fixed-station network in the Rhode Island region consists of five base stations-Providence, R.I. (NBC1); Fall River, MA (ABL1); Framingham, MA (KP16); Boston, MA (KP19); and Norwich, CT (MTG1). Quality-assurance GPS measurements were made at 36 NGS benchmarks (BMs) with vertical datum throughout the study area. The elevation of the GPS measured BMs yielded a vertical root mean square error (RMSE) of 0.10 and $0.14 \mathrm{ft}$ for the two field GPS units, respectively. 
Table 1-17. Summary of structures in the hydraulic model for Woonasquatucket River, Rhode Island.

[River station rounded to the nearest foot; AEP, annual exceedance probability; Inl Struct, in line structure; --, not applicable]

\begin{tabular}{|c|c|c|c|c|}
\hline \multirow{2}{*}{$\begin{array}{l}\text { River station } \\
\text { (feet) }\end{array}$} & \multirow{2}{*}{ Description } & \multirow{2}{*}{ Structure type } & \multicolumn{2}{|c|}{ 1-percent AEP flow } \\
\hline & & & Road overflow & Solution type \\
\hline 475 & Fox Point Hurricane Barrier & Inl Struct & -- & -- \\
\hline 1,372 & Point Street & Bridge & No & Energy \\
\hline 2,361 & Interstate 95 connector (abandoned) & Bridge & No & Energy \\
\hline 3,836 & South Water Street (pedestrian) & Bridge & No & Energy \\
\hline 3,917 & South Water Street & Bridge & No & Energy \\
\hline 4,317 & College Street (downstream pedestrian) & Bridge & No & Energy \\
\hline 4,373 & College Street & Bridge & No & Energy \\
\hline 4,409 & College Street (upstream pedestrian) & Bridge & No & Energy \\
\hline 4,933 & Washington Place & Bridge & No & Energy \\
\hline 5,154 & Steeple Street & Bridge & No & Energy \\
\hline 5,669 & Exchange Street & Bridge & No & Energy \\
\hline 5,945 & Pedestrian footbridge & Bridge & No & Energy \\
\hline 6,303 & Pedestrian footbridge & Bridge & No & Energy \\
\hline 6,613 & Francis Street & Bridge & No & Energy \\
\hline 6,900 & Railroad under Providence Mall & Bridge & No & Energy \\
\hline 7,240 & Park Street & Bridge & No & Energy \\
\hline 7,331 & Interstate 95 north on ramp & Bridge & No & Energy \\
\hline 7,455 & Interstate 95 & Bridge & No & Energy \\
\hline 7,514 & Interstate 95 south bound exit ramp & Bridge & No & Energy \\
\hline 8,845 & Bath Street (Kinsley crossover) & Bridge & No & Energy \\
\hline 9,090 & Kinsley (pedestrian) & Bridge & No & Energy \\
\hline 9,786 & Pleasant Valley Parkway/Dean Street & Bridge & No & Energy \\
\hline 10,347 & Acorn Street & Bridge & No & Energy \\
\hline 10,886 & Railroad (abandoned) & Bridge & No & Energy \\
\hline 11,050 & Private bridge & Bridge & Yes & Energy \\
\hline 12,449 & Eagle Street & Bridge & Yes & Energy \\
\hline 12,946 & Ericson Place (downstream bridge) & Bridge & Yes & Energy \\
\hline 13,230 & Ericson Place (upstream bridge) & Bridge & Yes & Energy \\
\hline 13,614 & Atwells Avenue & Bridge & Yes & Energy \\
\hline 15,315 & Valley Street & Bridge & Yes & Energy \\
\hline 15,965 & Rising Sun Dam & Inline & -- & -- \\
\hline 17,000 & Delaine Street & Bridge & No & Energy \\
\hline 17,351 & Paragon Dam (breached) & Inl Struct & -- & -- \\
\hline 18,190 & Manton Avenue & Bridge & $\mathrm{No}^{1}$ & Energy \\
\hline 18,515 & Shopping center & Bridge & $\mathrm{No}^{1}$ & Energy \\
\hline 18,985 & Factory extended parking deck & Bridge & $\mathrm{No}^{1}$ & Energy \\
\hline 19,210 & Factory building & Bridge & No & Energy \\
\hline 19,626 & Factory bridge & Bridge & Yes & Energy \\
\hline 19,954 & Unnamed dam & Inl Struct & -- & -- \\
\hline 21,682 & Bike and pedestrian & Bridge & No & Energy \\
\hline 22,085 & Route 6 (downstream) & Bridge & No & Energy \\
\hline
\end{tabular}


Table 1-17. Summary of structures in the hydraulic model for Woonasquatucket River, Rhode Island.—Continued

[River station rounded to the nearest foot; AEP, annual exceedance probability; Inl Struct, in line structure; --, not applicable]

\begin{tabular}{|c|c|c|c|c|}
\hline \multirow{2}{*}{$\begin{array}{l}\text { River station } \\
\text { (feet) }\end{array}$} & \multirow{2}{*}{ Description } & \multirow{2}{*}{ Structure type } & \multicolumn{2}{|c|}{ 1-percent AEP flow } \\
\hline & & & Road overflow & Solution type \\
\hline 23,894 & Route 6 (upstream) & Bridge & No & Energy \\
\hline 24,250 & Glenbridge Avenue & Bridge & No & Energy \\
\hline 25,752 & Bike path & Bridge & No & Energy \\
\hline 26,330 & Dyersville Pond Dam (removed) & Inline & -- & -- \\
\hline 29,434 & Manton Avenue & Bridge & No & Energy \\
\hline 30,425 & Lymansville Pond Dam & Inl Struct & -- & -- \\
\hline 33,934 & Lyman Mill Dam & Inl Struct & -- & -- \\
\hline 38,412 & Allendale Avenue (abandoned) & Bridge & No & Energy \\
\hline 38,527 & Allendale Pond Dam & Inline & -- & -- \\
\hline 42,080 & Putnam Pike/Smith Street/Route 44 & Bridge & No & Energy \\
\hline 43,736 & Private footbridge & Bridge & No & Energy \\
\hline 43,936 & Building & Bridge & No & Energy \\
\hline 44,043 & Debris protection piers & Bridge & Yes & Energy \\
\hline 44,175 & Centerdale Dam & Inl Struct & -- & -- \\
\hline 44,263 & Pedestrian footbridge & Bridge & No & Energy \\
\hline 44,628 & Pedestrian footbridge & Bridge & $\mathrm{No}^{1}$ & Energy \\
\hline 44,914 & Greystone/Angell Avenue & Bridge & No & Energy \\
\hline 45,152 & Greystone Dam & Inl Struct & -- & -- \\
\hline 48,718 & Esmond Mill Drive & Bridge & Yes & Energy \\
\hline 49,830 & Benny’s entrance & Bridge & Yes & Energy \\
\hline 50,240 & Benny’s Dam & Inl Struct & -- & -- \\
\hline 50,901 & Esmond Street & Bridge & No & Energy \\
\hline 51,157 & Bike path & Bridge & $\mathrm{No}^{1}$ & Energy \\
\hline 51,181 & Esmond Dam & Inl Struct & -- & -- \\
\hline 51,911 & Farnum Pike/Route 104 & Bridge & No & Energy \\
\hline 54,445 & Whipple Avenue & Bridge & No & Energy \\
\hline 55,352 & Stillwater Road (pedestrian) & Bridge & No & Energy \\
\hline 57,133 & Georgiaville Pond Dam & Inl Struct & NA & Energy \\
\hline 62,420 & Interstate 295 & Culvert & No & -- \\
\hline 62,832 & Capron Road & Culvert & Yes & -- \\
\hline 63,000 & Capron Pond Dam & Inl Struct & NA & Energy \\
\hline 65,220 & Stillwater Pond Dam & Inl Struct & NA & Energy \\
\hline 68,467 & George Washington Highway/Route 116 & Bridge & No & Energy \\
\hline 69,953 & Farnum Pike/Routes 5 and 104 & Bridge & Yes & Energy \\
\hline 70,342 & Stillwater/Woonasquatucket Reservoir & Inl Struct & NA & Energy \\
\hline 76,128 & Old Forge Road & Culvert & No & -- \\
\hline 79,442 & Routes 5 and 104 & Culvert & No & -- \\
\hline 79,565 & Railroad (abandoned) & Bridge & $\mathrm{No}^{1}$ & Energy \\
\hline 80,331 & Private drive & Bridge & Yes & Energy \\
\hline
\end{tabular}

${ }^{1}$ Road overflow at the 0.2 -percent AEP flow. 
Table 1-18. Comparison of U.S. Geological Survey measured coordinates and elevation to established National Geodetic Survey (NGS) benchmarks used for quality control of hydraulic model field surveys in Rhode Island.

[BM, benchmark; PID, permanent identifier; NGS, National Geodetic Survey, NAVD 88, North American Vertical Datum of 1988; NAD 83, North American Datum of 1983; WGS, World Geodetic System - minor differences with NAD 83 because of different reference ellipsoids. NAD 83 is stationary in time while WGS can shift in time but the WGS 84 and NAD 83 are intended to match; Delta, difference between established reference and surveyed coordinates or elevation; RMSE, root mean square error]

\begin{tabular}{|c|c|c|c|c|c|c|c|c|c|}
\hline \multirow{2}{*}{ BM PID } & \multicolumn{3}{|c|}{$\begin{array}{c}\text { Longitude } \\
\text { (decimal degrees-W) }\end{array}$} & \multicolumn{3}{|c|}{$\begin{array}{c}\text { Latitude } \\
\text { (decimal degrees) }\end{array}$} & \multicolumn{3}{|c|}{$\begin{array}{c}\text { Elevation } \\
\text { (feet above NAVD 88) }\end{array}$} \\
\hline & $\begin{array}{c}\text { NGS } \\
\text { NAD } 83\end{array}$ & $\begin{array}{c}\text { Surveyed } \\
\text { WGS } 84\end{array}$ & Delta & $\begin{array}{c}\text { NGS } \\
\text { NAD } 83\end{array}$ & $\begin{array}{c}\text { Surveyed } \\
\text { WGS } 84\end{array}$ & Delta & NGS & Surveyed & Delta \\
\hline LW1435 & 71.57944 & 71.57962 & -0.00018 & 41.75639 & 41.75654 & -0.00015 & 302.35 & 302.37 & -0.02 \\
\hline LW1347 & 71.56278 & 71.56279 & -0.00001 & 41.73017 & 41.73017 & 0.00000 & 202.54 & 202.51 & 0.03 \\
\hline LW1063 & 71.52181 & 71.52182 & -0.00001 & 41.70901 & 41.70900 & 0.00001 & 128.69 & 128.68 & 0.01 \\
\hline LW0452 & 71.43139 & 71.43149 & -0.00010 & 41.70694 & 41.70701 & -0.00007 & 42.14 & 42.15 & -0.01 \\
\hline LW0452 & 71.43139 & 71.43149 & -0.00010 & 41.70694 & 41.70701 & -0.00007 & 42.14 & 42.10 & 0.04 \\
\hline LW0350 & 71.47083 & 71.47071 & 0.00012 & 41.71611 & 41.71599 & 0.00012 & 68.52 & 68.50 & 0.02 \\
\hline LW0452 & 71.43139 & 71.43149 & -0.00010 & 41.70667 & 41.70701 & -0.00034 & 42.14 & 42.05 & 0.09 \\
\hline LW1352 & 71.56083 & 71.56074 & 0.00009 & 41.68556 & 41.68587 & -0.00031 & 226.19 & 226.17 & 0.02 \\
\hline LW1347 & 71.56278 & 71.56279 & -0.00001 & 41.73017 & 41.73017 & 0.00000 & 202.54 & 202.42 & 0.12 \\
\hline LW1352 & 71.56083 & 71.56074 & 0.00009 & 41.68556 & 41.68587 & -0.00031 & 226.19 & 226.07 & 0.12 \\
\hline LW1352 & 71.56083 & 71.56074 & 0.00009 & 41.68556 & 41.68587 & -0.00031 & 226.19 & 226.12 & 0.07 \\
\hline LW1351 & 71.55725 & 71.55726 & -0.00001 & 41.69186 & 41.69186 & 0.00000 & 246.14 & 246.07 & 0.07 \\
\hline LW0410 & 71.49222 & 71.49232 & -0.00010 & 41.86528 & 41.86532 & -0.00004 & 112.80 & 112.94 & -0.14 \\
\hline LW0440 & 71.43861 & 71.43884 & -0.00023 & 41.81556 & 41.81568 & -0.00012 & 53.08 & 52.90 & 0.18 \\
\hline LW0440 & 71.43861 & 71.43884 & -0.00023 & 41.81556 & 41.81568 & -0.00012 & 53.08 & 53.03 & 0.05 \\
\hline LW0440 & 71.43861 & 71.43884 & -0.00023 & 41.81556 & 41.81568 & -0.00012 & 53.08 & 52.98 & 0.10 \\
\hline LW0440 & 71.43861 & 71.43884 & -0.00023 & 41.81556 & 41.81568 & -0.00012 & 53.08 & 53.06 & 0.02 \\
\hline \multicolumn{10}{|c|}{ GPS-2 serial number 6111463172 ( acquired June 2011) } \\
\hline LW0410 & 71.49222 & 71.49232 & -0.00010 & 41.86528 & 41.86532 & -0.00004 & 112.84 & 112.61 & 0.23 \\
\hline LW1347 & 71.56278 & 71.56279 & -0.00001 & 41.73017 & 41.73017 & 0.00000 & 202.54 & 202.57 & -0.03 \\
\hline LW0410 & 71.49222 & 71.49232 & -0.00010 & 41.86528 & 41.86532 & -0.00004 & 112.84 & 112.75 & 0.09 \\
\hline LW0445 & 71.47861 & 71.47897 & -0.00036 & 41.82028 & 41.82038 & -0.00010 & 211.36 & 211.51 & -0.15 \\
\hline LW0316 & 71.38944 & 71.38976 & -0.00032 & 41.89889 & 41.89913 & -0.00024 & 64.77 & 64.67 & 0.10 \\
\hline LW0745 & 71.83147 & 71.83145 & 0.00002 & 41.37751 & 41.37750 & 0.00001 & 11.58 & 11.72 & -0.14 \\
\hline LW0411 & 71.48994 & 71.48995 & -0.00001 & 41.86596 & 41.86596 & 0.00000 & 138.42 & 138.39 & 0.03 \\
\hline LW0411 & 71.48994 & 71.48995 & -0.00001 & 41.86596 & 41.86596 & 0.00000 & 138.42 & 138.56 & -0.14 \\
\hline LW0745 & 71.83147 & 71.83145 & 0.00002 & 41.37751 & 41.37750 & 0.00001 & 11.58 & 11.43 & 0.15 \\
\hline LW0452 & 71.43139 & 71.43148 & -0.00010 & 41.70667 & 41.70701 & -0.00034 & 42.14 & 42.02 & 0.12 \\
\hline LW1492 & 70.99556 & 70.99562 & -0.00007 & 41.90278 & 41.90314 & -0.00036 & 24.15 & 23.89 & 0.26 \\
\hline \multirow[t]{3}{*}{ LW0316 } & 71.38944 & 71.38976 & -0.00032 & 41.89889 & 41.89913 & -0.00024 & 64.75 & 64.65 & 0.10 \\
\hline & & Mean & -0.00011 & & & -0.00011 & & & 0.05 \\
\hline & & & & & & & & RMSE & 0.14 \\
\hline
\end{tabular}




\section{References}

Ackerman, C.T., 2011, HEC-GeoRAS GIS tools for support of HEC-RAS using ArcGIS-user's manual (version 4.3.93): Davis, Calif., U.S. Army Corps of Engineers, Hydrologic Engineering Center, CPD-83, 244 p.

Brunner, G.W., 2010a, HEC-RAS river analysis system, user's manual (version 4.1): Davis, Calif., U.S. Army Corps of Engineers, Hydrologic Engineering Center, CPD-68, 766 p.

Brunner, G.W., 2010b, HEC-RAS river analysis system, hydraulic reference manual (version 4.1): Davis, Calif., U.S. Army Corps of Engineers, Hydrologic Engineering Center, CPD-69, $411 \mathrm{p}$.

FEMA - Federal Emergency Management Agency

FEMA, 1974, Flood Insurance Study, Town of North Providence: community no. 440020, prepared by the U.S. Department of Agriculture, Soil Conservation Service for the U.S. Department of Housing and Urban Development, Federal Insurance Administration, 15 p.

FEMA, 1982, Flood Insurance Study, Town of Lincoln: community no. 445400, prepared by Harris-Toups Associates for the U.S. Department of Housing and Urban Development, Federal Insurance Administration, 35 p.

FEMA, 1983, Flood Insurance Study, City of Providence: prepared by P.R.C. Harris, Boston, Mass., for the Federal Emergency Management Agency, Division of Insurance and Mitigation, $43 \mathrm{p}$.
FEMA, 2011, Guidelines and standards for flood hazard mapping partners, Appendix M—data capture standards: $170 \mathrm{p}$.

Johnson, C.G., and Laraway, G.A., 1976, Flood magnitude and frequency of small Rhode Island streams: U.S. Geological Survey Open-File Report 76-883, 20 p.

Providence Emergency Management Agency, 2011, Fox Point Hurricane Barrier (FPHB) coordination guide: unpublished report, $35 \mathrm{p}$.

Sauer, V.B., 1974, Flood characteristics of Oklahoma streams-Techniques for calculating magnitude and frequency of floods in Oklahoma, with compilations of flood data through 1971: U.S. Geological Survey WaterResources Investigations Report 73-52, 307 p.

U.S. Interagency Advisory Committee on Water Data, 1982, Guidelines for determining flood flow frequency: Reston, Va., U.S. Geological Survey, Office of Water Data Coordination, Bulletin 17B of the Hydrology Subcommittee, $183 \mathrm{p}$.

Warner, J.C., Brunner, G.W., Wolfe, B.C., and Piper, S.S, 2010, HEC-RAS river analysis system, applications guide (version 4.1): Davis, Calif., U.S. Army Corps of Engineers, Hydrologic Engineering Center, CPD-70, 351 p.

Zarriello, P.J., Ahearn, E.A., and Levin, S.B., 2012, Magnitude of flood flows for selected annual exceedance probabilities in Rhode Island, through 2010: U.S. Geological Survey Scientific Investigations Report 2012-5109, 93 p. (available at http://pubs.usgs.gov/sir/2012/5109/.) 
THIS PAGE INTENTIONALLY LEFT BLANK 
Prepared by the Pembroke and Columbus Publishing Service Centers.

For more information concerning this report, contact:

Office Chief

U.S. Geological Survey

New England Water Science Center

Massachusetts-Rhode Island Office

10 Bearfoot Road

Northborough, MA 01532

dc_ma@usgs.gov

or visit our Web site at:

http://ma.water.usgs.gov 
